\title{
Lack of Tau Proteins Rescues Neuronal Cell Death and Decreases Amyloidogenic Processing of APP in APP/PS1 Mice
}

\author{
Karelle Leroy, ${ }^{*}$ Kunie Ando, ${ }^{*}$ Vincent Laporte, ${ }^{\dagger}$ \\ Robert Dedecker, ${ }^{*}$ Valérie Suain, ${ }^{*}$ \\ Michèle Authelet, ${ }^{*}$ Céline Héraud, ${ }^{*}$ \\ Nathalie Pierrot, ${ }^{\dagger}$ Zehra Yilmaz, $^{*}$ \\ Jean-Noël Octave, ${ }^{\dagger}$ and Jean-Pierre Brion* \\ From the Laboratory of Histology, Neuroanatomy, and \\ Neuropathology," Université Libre de Bruxelles, Brussels; and the \\ Institute of Neuroscience, ${ }^{\dagger}$ Université Catbolique de Louvain, \\ Brussels, Belgium
}

Lack of tau expression has been reported to protect against excitotoxicity and to prevent memory deficits in mice expressing mutant amyloid precursor protein (APP) identified in familial Alzheimer disease. In APP mice, mutant presenilin 1 (PS1) enhances generation of $A \beta 42$ and inhibits cell survival pathways. It is unknown whether the deficient phenotype induced by concomitant expression of mutant PS1 is rescued by absence of tau. In this study, we have analyzed the effect of tau deletion in mice expressing mutant APP and PS1. Although APP/ PS1 $/ \mathrm{tan}^{+/+}$mice had a reduced survival, developed spatial memory deficits at 6 months and motor impairments at 12 months, these deficits were rescued in $A P P / P S 1 / \mathrm{tau}^{-/-}$mice. Neuronal loss and synaptic loss in $A P P / P S 1 / \mathrm{tau}^{+/+}$mice were rescued in the $A P P / P S 1 / \mathrm{tau}^{-/-}$mice. The amyloid plaque burden was decreased by roughly $50 \%$ in the cortex and the spinal cord of the $A P P / P S 1 / \mathrm{tau}^{-/-}$mice. The levels of soluble and insoluble $A \beta 40$ and $A \beta 42$, and the $\mathrm{A} \beta 42 / \mathrm{A} \beta 40$ ratio were reduced in $A P P / P S 1 / \mathrm{tau}^{-/-}$ mice. Levels of phosphorylated APP, of $\beta$-C-terminal fragments (CTFs), and of $\beta$-secretase 1 (BACE1) were also reduced, suggesting that $\beta$-secretase cleavage of APP was reduced in $A P P / P S 1 / \mathrm{tan}^{-/-}$ mice. Our results indicate that $t a u$ deletion had a protective effect against amyloid induced toxicity even in the presence of mutant PS1 and reduced the production of A $\beta$. (Am J Pathol 2012, 181:1928-1940; http://dx.doi.org/10.1016/j.ajpath.2012.08.012)
Alzheimer disease (AD) is neuropathologically characterized by the presence of neurofibrillary tangles and senile plaques. Neurofibrillary tangles consist of paired helical filaments, composed of abnormally phosphorylated forms of the microtubule-associated protein tau. Senile plaques have an extracellular core of amyloid surrounded by dystrophic neurites and reactive glial cells. The amyloid core is mainly composed of fibrillar aggregates of the amyloid- $\beta$ peptide $(A \beta)$, generated by proteolytic cleavage of the transmembrane amyloid precursor protein (APP). APP is thought to play a central role in the disease, eg, in view of familial forms of $A D$ due to mutations in APP. According to the amyloid cascade hypothesis, the $A \beta$ peptide, or oligomeric forms of it, is neurotoxic, leading to synaptic dysfunction, neuronal death, and formation of neurofibrillary tangles. Several results, however, have suggested that tau might influence the development of behavioral deficits and cellular abnormalities associated with amyloid pathology. For instance, cultured neurons treated with fibrillar $A \beta$ showed signs of degeneration, whereas neurons with a knockout tau gene were resistant to $A \beta$ toxicity. ${ }^{1}$ Also, tau was found to confer to microtubules hypersensitivity to depolymerization induced by prefibrillar $A \beta$ in cultured cells. ${ }^{2}$ Tau reduction in transgenic mice overexpressing mutant APP prevented the development of learning and memory deficits and increased their resistance to excitotoxin-induced seizures. ${ }^{3}$ Absence of tau has been suggested to reduce $A \beta$ toxicity at the postsynaptic level by uncoupling NMDA receptor-mediated excitotoxicity. ${ }^{4} A \beta$ impairs long-term potentiation, ${ }^{5}$ and tau has been reported to be required for this $A \beta$-induced impairment of long-

Supported by the Diane program (Walloon region) (816856) and by grants from the Fonds de la Recherche Scientifique Médicale (3.4504.10).

Accepted for publication August 9, 2012

K.L. and K.A. contributed equally to this work.

Supplemental material for this article can be found at http://ajp. amjpathol.org or at $h t t p: / / d x . d o i . o r g / 10.1016 / j$. ajpath.2012.08.012.

Address reprint requests to Jean-Pierre Brion, M.D., Ph.D., Laboratory of Histology, Neuroanatomy, and Neuropathology, School of Medicine, Université Libre de Bruxelles, 808, route de Lennik, Bldg GE, 1070 Brussels, Belgium. E-mail: jpbrion@ulb.ac.be. 
term potentiation, ${ }^{6}$ most probably through GSK-3 $3{ }^{6,7}$ Tau reduction also prevented $A \beta$-induced defects in axonal transport ${ }^{8}$ and behavioral deficits in APPxFyn mice. ${ }^{9}$ Deletion of tau in another APP mouse model led to an increased axonal degeneration instead. ${ }^{10}$ Presenilin 1 (PS1) is necessary for $\gamma$-cleavage of APP and generation of $A \beta$, and mutant PS1 (found in familial forms of $A D$ ) enhances formation of $A \beta 42$ in mice overexpressing mutant APP. PS1, however, also binds both tau and GSK-3 $\beta$, and mutant PS1 binds more GSK-3 $\beta$, inducing increased tau phosphorylation. ${ }^{11}$ Wild-type PS1 prevents apoptosis by activating PI3K/Akt signaling and inhibiting GSK-3 $\beta$ activity, whereas the mutant form of PS1 inhibits PI3K/Akt cell survival pathway by promoting GSK-3 $\beta$ activity. ${ }^{12}$ Thus, mutant PS1 affects amyloidogenic processing of APP but has additional deleterious effects on cell survival.

To further analyze the link between tau expression and APP/A $\beta$ toxicity, neuronal loss, and APP processing, and to know whether the protective effect of tau reduction was also present when mutant forms of PS1 were expressed, we have generated a new model expressing both of the mutants APP and PS1 in absence of tau. We observed that tau inactivation, not only improved memory and motor deficits in APP/PS1 mice, but also rescued neuronal cell death and decreased $A \beta$ load.

\section{Materials and Methods}

\section{Generation of Transgenic Mice}

The 5xFAD (hereafter called APP/PS1/tau ${ }^{+/+}$) heterozygote Tg6799 mice contain five familial AD mutations for APP (K670N/M671L, 1716V, and V717I) and for PS1 (M146L and L286V). ${ }^{13}$ Mutant APP and PS1 transgene expression is driven by the mouse Thy 1 promoter. The tau $^{-1-}$ mouse line (the Jackson Laboratory, Bar Harbor, $\mathrm{ME}$ ) was generated by knockin of the EGFP coding sequence into the first exon of the tau gene. ${ }^{14}$ Both the APP/PS1 and tau ${ }^{-1-}$ lines were maintained on a C57BL6 background. APP/PS1/tau ${ }^{+/+}$mice were crossed with tau $^{-/-}$mice to generate $\mathrm{F}_{1}$ APP/PS1/tau ${ }^{+/-}$mice. APP/ $P S 1 / \mathrm{tau}^{+/-}$mice were then bred with $\mathrm{tau}^{+/-}$mice to generate $\mathrm{F}_{2}$ APP/PS1/tau ${ }^{-/-}$mice and littermates APP/ PS1/tau ${ }^{+/+}$, APP/PS1/tau ${ }^{+/-}, \operatorname{tau}^{-/-}, \operatorname{tau}^{+/-}$, and $\operatorname{tau}^{+/+}$ (wild-type) mice with the same genetic background. Only the representative four genotypes $\left(\mathrm{tau}^{+/+}, \mathrm{tau}^{-/-}, \mathrm{APP} /\right.$ PS1/tau ${ }^{+/+}$, and APP/PS1/tau ${ }^{-/-}$) from the same littermates were further analyzed. Genotyping was performed by three independent PCR amplifications of DNA extracted from tail DNA using previously described primers for human APP ${ }^{13}$ murine tau, and GFP. ${ }^{15}$ All studies on animals were performed in compliance and following approval of the ethical committee for the care and use of laboratory animals of the Medical School of the Free University of Brussels.

\section{Motor and Behavioral Testing}

Motor deficits were assessed with the rotarod test, as previously described. ${ }^{15,16}$ Mice were placed on a rod rotating with a progressive acceleration from 4 to $40 \mathrm{rpm}$ in 5 minutes. Mice were first trained with three trials per day during 3 days, and the latency that mice spent on the rotating rod before falling was measured on the third day. Spatial working memory was investigated as previously described using a $Y$ maze and assessment of spontaneous alternation. ${ }^{17}$ Each mouse was placed at the end of one arm and was allowed to explore freely for 8 minutes, during which their movements were recorded with a digital camera. Records were analyzed by an observer blinded to the genotype that encoded the sequence and the total number of arms entered offline. An entry was considered when the four paws were in the arm. Spontaneous alternation was computed as the number of triads containing entries in the three arms divided by the total number of arms minus two.

\section{Antibodies}

The B19 antibody is a rabbit polyclonal antibody raised to adult bovine tau proteins, reacting with adult and fetal tau isoforms in bovine, rat, mouse, and human nervous tissue in a phosphorylation-independent manner. ${ }^{18}$ The mouse monoclonal anti-APP antibody $3 \mathrm{H} 5$ is specific for human APP. ${ }^{19}$ The BR15 rabbit polyclonal antibody was raised against a synthetic peptide corresponding to the last 20 amino acids of human APP, conjugated to purified protein derivative, and reacts with mouse and human APP. The rabbit polyclonal APP antibodies APPCter-C17 (to the C-terminus of human APP) and APP668P (to a human APP peptide phosphorylated on its Thr668) were kindly provided by Drs. Nicolas Sergeant and Luc Buée (INSERM U837, France) ${ }^{20}$ For detection of $A \beta$, we used a rabbit polyclonal antibody specific for $A \beta 40$ (BioSource; purchased from Invitrogen, Carlsbad, CA), a rabbit polyclonal antibody specific for $A \beta 42$ (purchased from Millipore, Billerica, MA), and a mouse monoclonal antibody raised to amino acids 1 to 16 of the $A \beta$ peptide (6E10; purchased from Covance, Princeton, $\mathrm{NJ}$ ). A rat monoclonal antibody to human PS1 was purchased from Chemicon (MAB1563; Chemicon/Millipore, Billerica, MA). The rabbit polyclonal anti-PS1 antibody (SB129) recognizes both human and murine PS1 (generously provided by Dr. Christine Van Broeckhoven, UIA, Belgium). ${ }^{21}$ The BR6 rabbit polyclonal antibody was raised against cathepsin B from bovine spleen (Sigma C6286; Sigma-Aldrich, St. Louis, MO), and reacts with mouse and human cathepsin B. The following additional antibodies were also used: mouse monoclonal antibodies to $\alpha$-tubulin (clone DM1-A) and to $\beta$-actin (clone AC15) (Sigma-Aldrich, Bornem, Belgium), to GSK-3 $\beta$ (TPK1) (BD Transduction Laboratories; BD Biosciences, San Jose, CA), to synaptophysin (clone YE269) and PSD95 (clone K28/43) (Millipore), rabbit polyclonal antibodies to BACE1 (Rockland Immunochemicals, Gilbertsville, PA), to GSK- $3 \alpha / \beta$ phosphorylated on Ser21/9 (Cell Signaling Technology, Danvers, MA), and to GSK-3 $\alpha / \beta$ phosphorylated on Tyr276/Tyr216 (BioSource; Invitrogen). 


\section{Preparation of Brain and Spinal Cord Homogenates}

Samples were homogenized in 10 volumes of radioimmunoprecipitation assay (RIPA) buffer $[50 \mathrm{mmol} / \mathrm{L}$ Tris $(\mathrm{pH}$ 7.4) containing $150 \mathrm{mmol} / \mathrm{L} \mathrm{NaCl}, 1 \% \mathrm{NP}-40,0.25 \%$ sodium deoxycholate, $1 \mathrm{mmol} / \mathrm{L}$ phenylmethylsulfonyl fluoride, $25 \mu \mathrm{g} / \mathrm{mL}$ leupeptin, $25 \mu \mathrm{g} / \mathrm{mL}$ pepstatin, $10 \mathrm{mmol} / \mathrm{L}$ sodium pyrophosphate, $20 \mathrm{mmol} / \mathrm{L}$ sodium fluoride, 1 $\mathrm{mmol} / \mathrm{L}$ sodium orthovanadate] for brains and in $20 \mathrm{vol}-$ umes for the spinal cords. The homogenate was centrifuged $\left(20,000 \times g\right.$ for 20 minutes at $\left.4^{\circ} \mathrm{C}\right)$, and the supernatant was used as a soluble fraction. The pellet was resuspended in threefold volume of $100 \%$ formic acid by vigorous pipetting and vortexing, followed by incubation overnight at $4^{\circ} \mathrm{C}$ on a rotator. The mixture was centrifuged at $20,000 \times g$ at $4^{\circ} \mathrm{C}$ for 20 minutes. The supernatant was neutralized with 19 volumes of $2 \mathrm{~mol} / \mathrm{L}$ Tris buffer. This formic acid fraction was used as the insoluble fraction.

\section{Western Blot Analysis}

Protein concentrations were estimated by the Bradford method (Bio-Rad Laboratories, Hercules, CA). Tissue samples (100 $\mu \mathrm{g} /$ lane) were run in either $7.5 \%$ or $10 \%$ Tris-glycine gels or $16 \%$ Tris-Tricine gels and then transferred onto nitrocellulose membranes. The nitrocellulose sheets were blocked in semifat dry milk [10\% (w/v) in Tris-buffered saline] for 1 hour at room temperature and then incubated with primary antibodies overnight followed by anti-rabbit or anti-mouse immunoglobulins conjugated to alkaline phosphatase (Sigma-Aldrich) or peroxidase (for the electrochemiluminescence method). Finally, the membranes were incubated in developing buffer [0.1 mol/L Tris, $0.1 \mathrm{~mol} / \mathrm{L} \mathrm{NaCl}, 0.05 \mathrm{~mol} / \mathrm{L} \mathrm{MgCl}_{2}$ ( $\mathrm{pH}$ 9.5)] containing nitro blue tetrazolium at a concentration of $0.33 \mathrm{mg} / \mathrm{mL}$ and 5-bromo-4-chloro-3-indolyl phosphate at a concentration of $0.175 \mathrm{mg} / \mathrm{mL}$ or in SuperSignal West Pico substrate (Pierce Biotechnology, Thermo Fisher Scientific, Waltham, MA). The development was stopped by dipping the membranes in 10 $\mathrm{mmol} / \mathrm{L}$ Tris, $1 \mathrm{mmol} / \mathrm{L}$ EDTA $(\mathrm{pH} 8)$ or after exposure of an X-ray film. The levels of expression of transgenic proteins and fragments of APP were estimated by densitometry analysis using the NIH Image $J$ program $(\mathrm{NIH}$, Bethesda, MD), and adjusted for protein loading based on immunoblots performed with the anti-actin antibody.

\section{Immunoprecipitation}

Co-immunoprecipitations for PS1, APP, and GSK-3 $\beta$ were performed using a Rabbit TrueBlot IP kit (eBioscience, San Diego, CA) following the manufacturer's instructions. Briefly, the RIPA soluble fraction was precleared with pre-equilibrated Rabbit TrueBlot bead slurry. Pre-cleared samples were incubated overnight on a rotator with the anti-PS1 SB129 antibody. Protein complexes were precipitated with Rabbit TrueBlot beads followed by repetitive washes. After the third wash, SDS sample buffer containing $5 \% \quad \beta$-mercaptoethanol was added to the beads, and the samples were heated at $37^{\circ} \mathrm{C}$ for PS1 and at $100^{\circ} \mathrm{C}$ for the other proteins.

\section{ELISA}

In the soluble and insoluble fractions of brain and spinal cord of 6-month-old mice, we measured the concentration of three species of $\beta$-amyloid peptide, $A \beta 38, A \beta 40$, and $A \beta 42$, by electrochemiluminescence immunoassay. Its principle was described by Best et $\mathrm{al}^{22}$ and the assays were performed according to the manufacturer's instructions. Briefly, samples were analyzed using Meso Scale Discovery SECTOR Imager 2400 [Meso Scale Discovery (MSD), Gaithersburg, MD], with the human $A \beta$ triplex kit (also from MSD); the 96-well carbon electrode plates contained four capture spots in each well, one of which was blocked with bovine serum albumin (as the standard curve control), and the three others coated with isoform-specific anti- $A \beta$ antibodies specific for $A \beta 38$, $A \beta 40, A \beta 42$, respectively. A total of $100 \mu \mathrm{L}$ of blocking buffer solution was added to all wells to avoid nonspecific binding. The plates were then sealed, wrapped in a thin foil, and then incubated at room temperature on a plate shaker $(600 \mathrm{rpm})$ for 1 hour. At the end of the incubation, the wells were washed three times with washing buffer. The samples and $25 \mu \mathrm{L}$ of the standards $(A \beta 38, A \beta 40$, and $A \beta 42)$ were then added to the wells, followed by an A $\beta$-detecting antibody (MSD) at $1 \mu \mathrm{g} / \mathrm{mL}$ labeled with a ruthenium (II) tris-bipyridine $N$-hydroxysuccinimide ester; this detection antibody is 6E10 (recognizing, specifically, amino acids 3 to 8 of human $A \beta$ ). Plates were then aspirated and washed three times. MSD read buffer (containing tripropylamine) was added to the wells before reading on the Sector Imager, and a small electric current through the microelectrodes present in each well was used to produce a redox reaction of the $\mathrm{Ru}^{2+}$ cation, with emission of a measured 620-nm red light ray. Using dose-response curves, we calculated the concentration of each $A \beta$ isoform for each sample, the blank being wild-type homogenates.

\section{Histological Staining and Immunohistochemistry}

Mice were sacrificed by cervical dislocation, and after dissection, the brains and spinal cords were fixed in 10\% formalin for 24 hours before embedding in paraffin. Tissue sections (7 $\mu \mathrm{m}$ thick) were stained with hematoxylin \& eosin and the Nissl method for histological examination, and also with Congo Red and with thioflavin S for detection of aggregated amyloid deposits. For immunohistochemistry, sections were processed as previously described. ${ }^{23}$ Briefly, they were incubated in $\mathrm{H}_{2} \mathrm{O}_{2}$ to inhibit endogenous peroxidase, rinsed in water, and then incubated with a blocking solution [10\% of normal rabbit serum in TBS [0.01 mol/L Tris, $0.15 \mathrm{~mol} / \mathrm{L} \mathrm{NaCl}(\mathrm{pH} 7.4)]$. The sections were then incubated overnight with the primary antibody and then incubated with anti-mouse or anti-rabbit antibodies conjugated to biotin (Vector Laboratories, Burlingame, CA) followed by the $\mathrm{ABC}$ complex (Vector Laboratories). Diaminobenzidine was used as a substrate for revealing peroxidase activity. Double immu- 
nofluorescent labeling was performed as previously reported, using horse anti-mouse antibody conjugated to fluorescein isothiocyanate (the Jackson Laboratory) and horse anti-rabbit antibodies conjugated with biotin (Vector Laboratories) and streptavidin-conjugated Alexa594 (Molecular Probes/Invitrogen, Carlsbad, CA). For immunolabeling with the $A \beta$ antibodies, rehydrated tissue sections were pre-treated with $100 \%$ formic acid for 10 minutes before incubation with the blocking solution. Tissue sections were examined with a Zeiss Axioplan microscope and digital images acquired using an Axiocam HRc camera, and an ApoTome system (Carl Zeiss, Oberkochen, Germany) for double immunofluorescent labeling.

\section{Stereological Analysis}

Formalin $10 \%(v / v)$ fixed and paraffin-embedded samples were serially cut in coronal sections $(15 \mu \mathrm{m}$ thickness) and stained with Cresyl violet; stereological analysis was performed as reported previously. ${ }^{15,16}$ For the estimation of the neuron number in the pyramidal layer of the hippocampus in 12-month-old mice, we used 10 coronal sections at 225- $\mu \mathrm{m}$ intervals for each animal $(n=4)$. The counting was performed with a $100 \times$ oil objective with the Stereo Investigator software (version 9; MicroBrightField, Colchester, VT) on a motorized Zeiss Axio Imager M1 microscope. Optical disectors (30 $\mu \mathrm{m} \times 30$ $\mu \mathrm{m} \times 9 \mu \mathrm{m}$ ) were randomly and automatically distributed throughout the region of interest. Each pyramidal neuron whose nucleolus came into focus within an optical disector was counted. Estimation of the total number of pyramidal cells was calculated using the number of counted neurons and the volume of the pyramidal layer (Gundersen coefficient of error: $0.035 \pm 0.009$; Schmitz-Hof coefficient of error: $0.035 \pm 0.007$ ). An estimation of neuronal density was done on lumbar spinal cords using 11 cross sections at $75-\mu \mathrm{m}$ intervals for each animal $(n=4)$. Optical disector $(50 \mu \mathrm{m} \times 50 \mu \mathrm{m} \times 12 \mu \mathrm{m})$ were randomly and automatically distributed throughout the anterior horn of spinal cord. The density of neurons was calculated from the numbers of counted neurons per volume of spinal gray matter estimated according to Cavalieri's principle.

\section{Quantification of Extracellular A $\beta$ Plaque Load}

Quantification of extracellular amyloid deposits after immunolabeling with anti-A $\beta 40$ and anti-A $\beta 42$ antibodies in 6-month-old mice was performed in the cortex on sagittal sections taken near the midline and in the cervical spinal cord on cross sections. Virtual slices of whole brain or spinal cord sections were acquired with a camera (CX9000) mounted onto a Zeiss Axio Imager M1 microscope using the Stereo Investigator program, and pictures were binarized to 8-bit black and white images with the Image J program (version 1.41; NIH). After delimiting the cortex, the hippocampus, and the gray matter of the spinal cord in each image, the $A \beta$ immunolabeled areas were measured in these regions by detecting positive pixels using a constant threshold (manually optimized)
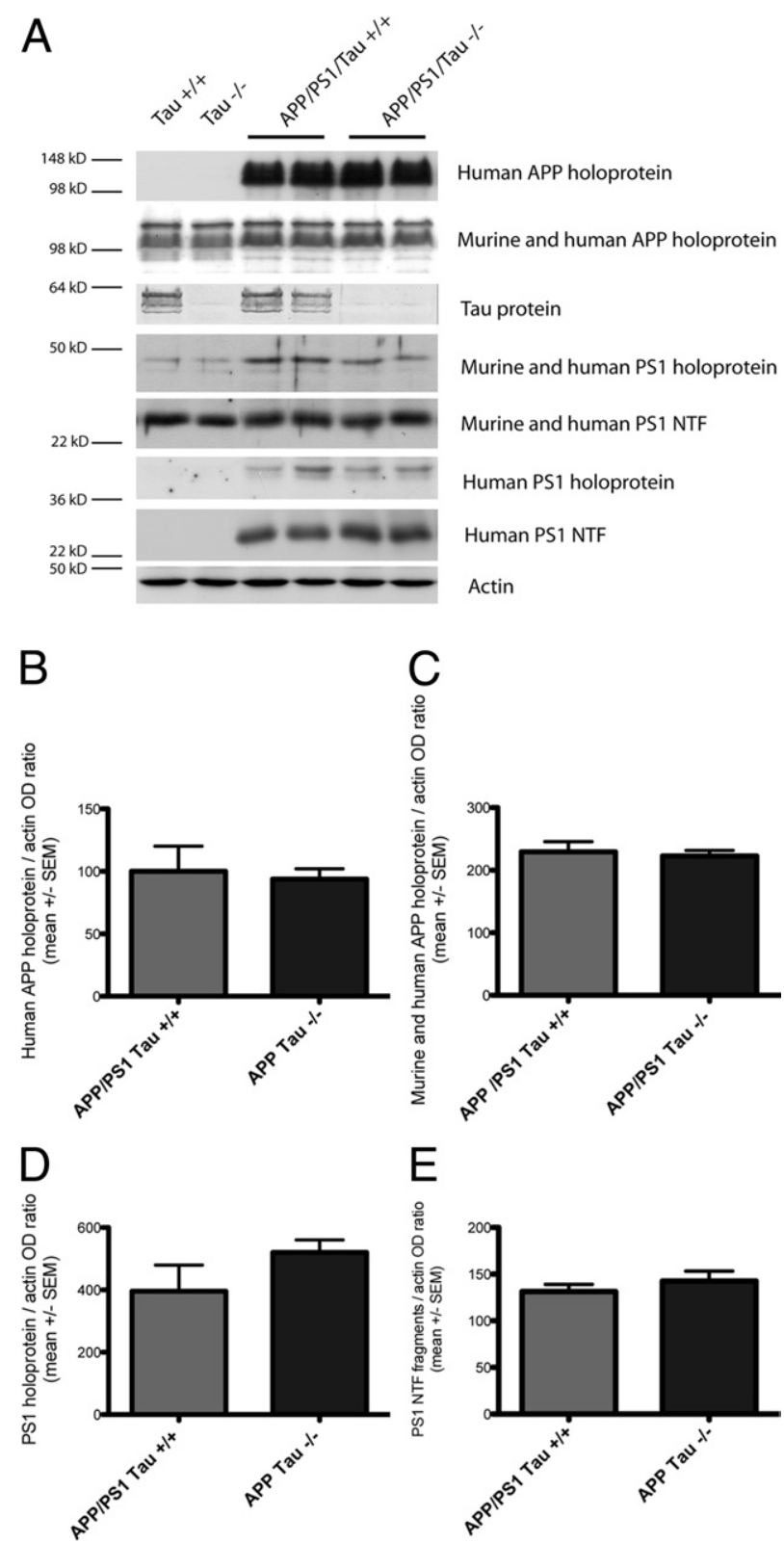

Figure 1. Levels of expression of APP and PS1 human transgenic proteins are similar in $A P P / P S 1 / \operatorname{tau}^{+/+}$and $A P P / P S 1 / \operatorname{tau}^{-/-}$mice. A: Western blots of brain homogenates of $\operatorname{tau}^{+/+}, \operatorname{tau}^{-/-}, A P P / P S 1 / \operatorname{tau}^{+/+}$, and APP/PS1/ $\operatorname{tau}^{-/-}$mice with antibodies against human APP (3H5), murine and human APP (BR15), tau (B19), murine and human PS1 (SB129), and human PS1 (MAB1563). An actin antibody was used as a control for protein load. Molecular weight markers: $148 \mathrm{kDa}$ (phosphorylase), $98 \mathrm{kDa}$ (bovine serum albumin), $64 \mathrm{kDa}$ (glutamic dehydrogenase), $50 \mathrm{kDa}$ (alcohol dehydrogenase), $36 \mathrm{kDa}$ (carbonic anhydrase), and $22 \mathrm{kDa}$ (myoglobin red). B-E: Densitometry analysis. The levels of human APP (B), total APP (murine and human) (C), human PS1 (holoprotein) (D), and human PS1 N-terminal fragment $(\mathbf{E})$ are similar in $A P P / P S 1 / \operatorname{tau}^{+/+}(n=7)$ and APP/PS1/tau ${ }^{-/}$ $(n=7)$ mice. Tau proteins are not expressed in $\mathrm{tau}^{-1-}$ and APP/PS1/tau ${ }^{-1}$ mice.

with the Image $\mathrm{J}$ program, and were expressed as a percentage of the total surface of the cortex, the hippocampus, and the gray matter of the spinal cord. The density of amyloid plaques and their mean size were calculated from the number of objects selected by setting thresholds with the Image $\mathrm{J}$ program. 
Tau + /+

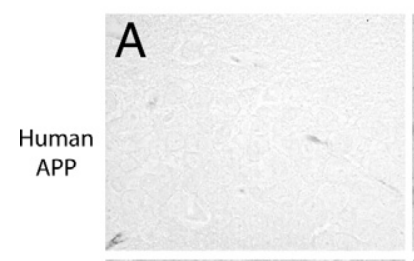

PS1
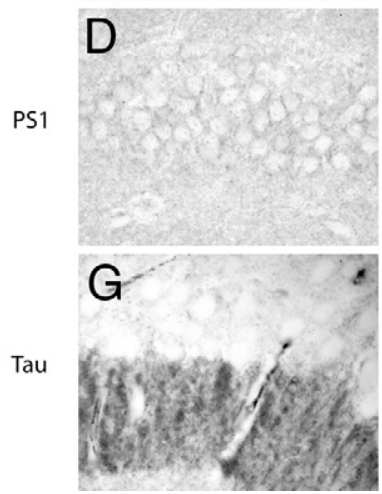
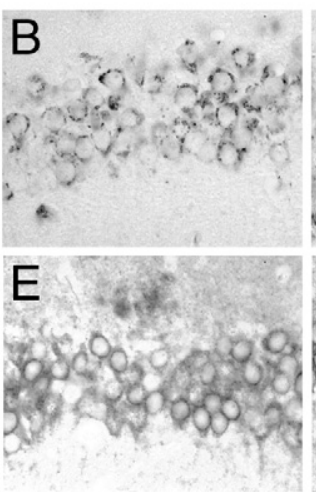

APP/PS1/Tau +/+

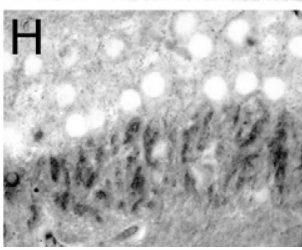

APP/PS1/Tau -/-
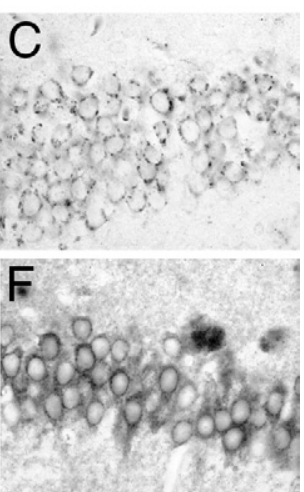

I.

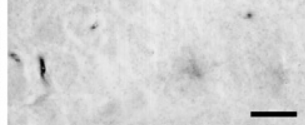

Figure 2. Neuronal expression of human APP and PS1 in $A P P / P S 1 / \tan ^{+/+}$and APP/PS1/tau ${ }^{-/-}$mice. Immunocytochemical detection of human APP ( $3 \mathrm{H} 5$ antibody) (A, B, and C), PS1 (SB129 antibody) (D, E, and F), and tau (B19 antibody) (G, $\mathbf{H}$, and $\mathbf{I})$ in hippocampus of $\operatorname{tau}^{+/+}(\mathbf{A}, \mathbf{D}$, and $\mathbf{G})$, $A P P / P S 1 / \operatorname{tau}^{+/+}(\mathbf{B}, \mathbf{E}$, and $\mathbf{H})$, and $A P P / P S 1 / \operatorname{tau}^{-/-}(\mathbf{C}, \mathbf{F}$, and $\mathbf{I})$ mice $(n=3)$. Human APP and PS1 are expressed in neurons of the pyramidal layer in $A P P / P S 1 / \tan ^{+/+}$and $A P P /$ PS1/tau ${ }^{-/}$mice. The PS1 antibody also detects endogenous PS1 in $\operatorname{tau}^{+/+}$mice (D). Tau immunoreactivity is strong in axonal Mossy fibers in $\operatorname{tau}^{+/+}$and in APP/PS1/tau ${ }^{+/+}$mice (G and $\mathbf{H}$ ) but is absent in APP/PS1/tau ${ }^{-1-}$ mice (I). Scale bar $=$ $50 \mu \mathrm{m}$.

\section{Analysis of Spine Density after Golgi Staining}

Golgi-Cox impregnation and staining of $150 \mu \mathrm{m}$ thick tissue sections from brain and spinal cord were performed using the FD Rapid GolgiStain kit (FD NeuroTechnologies, Columbia, MD). Fully impregnated cortical neurons from layer 5 were randomly selected for spine density analysis using the Neurolucida program (version 9; MicroBrightField), using a $100 \times$ oil objective. The firstorder apical dendrite of each pyramidal neuron was selected and tracing started from its cell body origin to a distance of $150 \mu \mathrm{m}$. Each dendritic spine along this dendritic segment was marked by an observer blinded to the genotype and spine density calculated for each neuron.

\section{Ultrastructural Analysis in Electron Microscopy}

Control and transgenic animals were anesthetized with ketamine hydrochloride and xylazine, and perfused intracardially with a solution of $2 \%(\mathrm{w} / \mathrm{v})$ paraformaldehyde and $2 \%(\mathrm{v} / \mathrm{v})$ glutaraldehyde in $0.1 \mathrm{~mol} / \mathrm{L}$ phosphate buffer at pH 7.4. Tissue blocks of the spinal cord, hippocampus, and of the cerebral cortex were dissected and further fixed by immersion in $4 \%(\mathrm{w} / \mathrm{v})$ glutaraldehyde in $0.1 \mathrm{~mol} / \mathrm{L}$ phosphate buffer at $\mathrm{pH} 7.4$ for 90 minutes. After washing in Millonig's buffer with $0.5 \%(\mathrm{w} / \mathrm{v})$ sucrose for 24 hours, the tissue blocks were postfixed in $2 \%(\mathrm{w} / \mathrm{v}) \mathrm{OsO}_{4}$ for 30 minutes, dehydrated, and then embedded in Epon. Semithin sections were stained with toluidine blue. Ultrathin sections were counterstained with uranyl acetate and lead citrate, and observed with a Zeiss EM 809 transmission electron microscope at $80 \mathrm{kV}$.

\section{Statistical Analysis}

Statistical significance was determined by unpaired Student's t-test and by one-way or two-way analysis of vari- ance (with Bonferroni post hoc test) using Prism 4 software (GraphPad Software, La Jolla, CA).

\section{Results}

Levels of Expression of APP and PS1 Are Similar in APP/PS1/tau ${ }^{+/+}$and APP/PS1/tau ${ }^{-/-}$Mice

APP/PS1/tau ${ }^{-1-}$ mice bearing human APP and PS1 mutant transgenes and with two inactivated tau alleles were analyzed by comparison with their littermates. The expression profiles of APP, PS1, and tau proteins in brain homogenates of $\mathrm{tau}^{+/+}$(wild-type), $\mathrm{tau}^{-/-}$, APP/PS1/ $\mathrm{tau}^{+/+}$, and APP/PS1/tau ${ }^{-/-}$mice are shown in Figure $1 \mathrm{~A}$. The expression levels of full-length APP detected by anti-human APP and anti-APP Cter antibodies and of PS1 (N-terminal fragment and holoprotein) were not different between APP/PS1/tau ${ }^{+/+}$and APP/PS1/tau ${ }^{-/-}$mice (Figure 1, B-E). Tau proteins were not expressed in tau $^{-1-}$ and APP/PS1/tau ${ }^{-1-}$ mice. Similar expression profiles were obtained in the spinal cord (data not shown). Immunocytochemical labeling confirmed the neuronal expression of human APP (Figure 2, A-C) and PS1 (Figure 2, D-F) in APP/PS1/tau ${ }^{+/+}$and APP/PS1/ $\mathrm{tau}^{-1-}$ mice, and the absence of expression of tau in APP/PS1/tau ${ }^{-1-}$ mice (Figure 2l). Dystrophic neurites around the plaques were labeled with the APP and PS1 antibodies in APP/PS1/tau ${ }^{+/+}$and APP/PS1/tau ${ }^{-/-}$ brains, and with tau antibodies in APP/PS1/tau ${ }^{+/+}$brains.

\section{Reduced Survival of APP/PS1/tau ${ }^{+/+}$Mice /s Partially Rescued in the Absence of tau}

Kaplan-Meier survival curves of $\operatorname{tau}^{+/+}, \mathrm{tau}^{-/-}$, APP/PS1/ tau $^{+/+}$, and APP/PS1/tau ${ }^{-/-}$mice were analyzed up to 12 months of age (Figure 3A). APP/PS1/tau ${ }^{+/+}$mice, but not $A P P / P S 1 /$ tau $^{-1-}$ mice, showed a significantly re- 
A

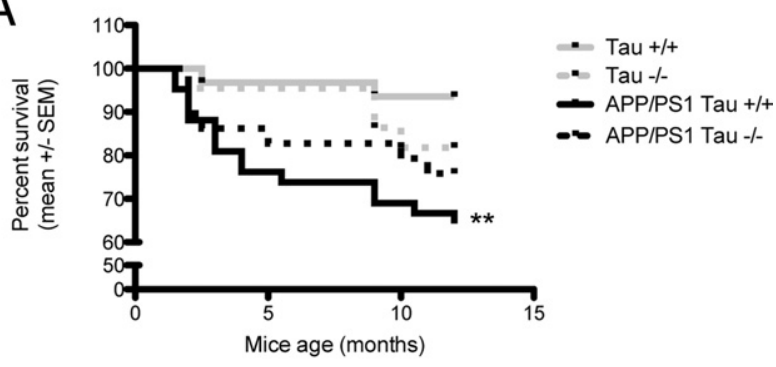

B

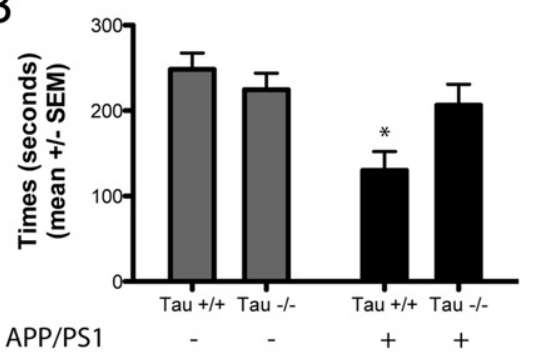

C

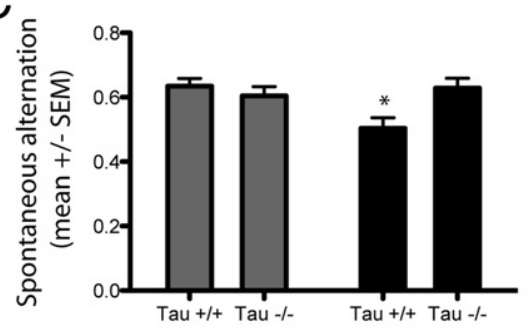

h APP/PS1

Figure 3. Motor deficits, working memory deficits, and reduced survival in APP/PS1/tau ${ }^{+/+}$mice are rescued in APP/PS1/tau ${ }^{-/-}$mice. A: Kaplan-Meir survival curve of $\tan ^{+/+}(n=31), A_{P P / P S 1 / t a u}^{+/+}(n=25), \operatorname{tau}^{-/-}(n=$ $21)$, and $A P P / P S 1 / \operatorname{tau}^{-/-}(n=28)$ mice. $A P P / P S 1 / \tan ^{+/+}$mice, but not $A P P / P S 1 / \tan ^{-1-}$ mice, show a reduced survival compared to $\tan ^{+/+}$mice. ${ }^{*}{ }^{*} P<0.01$, by log-rank test. B: Rotarod testing of $\operatorname{tau}^{+/+}(n=7), \operatorname{tau}^{-/-}$ $(n=8), A P P / P S 1 / \tan ^{+/+}(n=12)$, and APP/PS1/tau ${ }^{-/-}(n=12)$ mice at 12 months of age. The time spent on the rotating rod differs by genotype ( $A P P / P S 1$ by tau interaction, $P<0.05$, two-way analysis of variance): it is significantly reduced for the $A P P / P S 1 / \mathrm{tau}^{+/+}$mice compared to all other genotypes and is rescued in the $A P P / P S 1 / \mathrm{tau}^{-/-}$mice. ${ }^{*} P<0.05$, Bonferroni post hoc test. C: Spatial working memory was investigated by measuring spontaneous alternations in a Y maze for $\operatorname{tau}^{+/+}(n=18), \operatorname{tau}^{-/-}(n=8)$, APP/PS1/tau ${ }^{+/+}(n=9)$, and APP/PS1/tau ${ }^{-1-}(n=9)$ mice at 6 months of age. The number of alternations differs by genotype (APP/PS1 by tau interaction, $P<0.05$, two-way analysis of variance). The $A P P / P S 1 / t_{a u}^{+/+}$mice show significantly lower spontaneous alternations than $\operatorname{tau}^{+/+}$mice and APP/PS1/tau ${ }^{-1-}$ mice $\left({ }^{*} P<0.05\right.$, Bonferroni post hoc test).

duced survival (eg, 25\% mortality at 5 months) compared to $\mathrm{tau}^{+/+}$mice. APP/PS1/tau ${ }^{+/+}$mice were observed to have a higher frequency of sudden death and occasional convulsive seizures. Survival of $\mathrm{tau}^{-\prime-}$ mice, although showing a tendency to decrease after 10 months, was not significantly different from the other genotypes, as reported previously. ${ }^{3,9}$ The evolution of body weight was also analyzed from 3 months to 12 months in the four genotypes. Body weights were not different at 3 months between the different genotypes, but APP/PS1/tau ${ }^{+/+}$ mice had significantly lower body weights than APP/PS1/ tau $^{-\prime-}$ mice at 6,9 , and 12 months $(P<0.05$, by oneway-analysis of variance) (data not shown).
Motor Deficits and Working Memory Deficits in APP/PS1/tau ${ }^{+/+}$Mice Are Rescued in APP/PS1/tau ${ }^{-1-}$ Mice

APP/PS1/tau ${ }^{+/+}$mice showed a significant motor deficit by rotarod testing at 12 months of age, by comparison with wild-type and $\mathrm{tau}^{-1-}$ mice (Figure 3B): the time spent by APP/PS $1 / \mathrm{tau}^{+/+}$mice on the rotating rod before falling was $50 \%$ of the time spent by tau ${ }^{+/+}$and $\operatorname{tau}^{-/-}$mice. By contrast, the time spent by APP/PS1/tau ${ }^{-1-}$ mice was significantly higher than for APP/PS1/tau ${ }^{+/+}$mice and not different from $\mathrm{tau}^{+/+}$and $\mathrm{tau}^{-/-}$mice.

Working spatial memory was studied by assessing spontaneous alternations in $Y$ maze in 6 month-old mice (Figure 3C). At this age, APP/PS1/tau ${ }^{+/+}$mice had no motor deficits, and their exploratory activity, as measured by the number of arm entries, was similar to that in other genotypes (data not shown; not significant by two-way analysis of variance). APP/PS1/tau ${ }^{+/+}$mice, however,
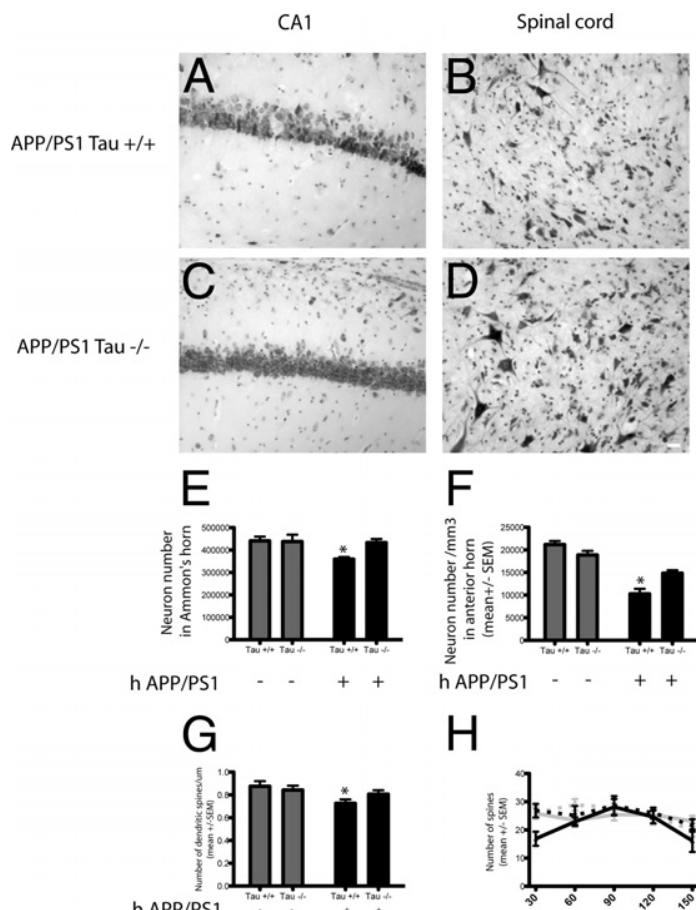

F

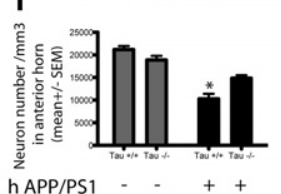

h APP/PS1

$\mathrm{H}$

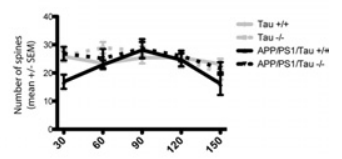

Figure 4. $A P P / P S 1 / \mathrm{tau}^{+/+}$mice, but not $A P P / P S 1 / \mathrm{tau}^{-/-}$mice, show a neuronal loss and a decreased spine density. A-D: Cresyl violet staining of sector 1 of Ammon's horn in the hippocampus (A and $\mathbf{C}$ ) and of the anterior horn of spinal cord $(\mathbf{B}$ and $\mathbf{D})$ of $A P P / P S 1 / \tan ^{+/+}(\mathbf{A}$ and $\mathbf{B})$ and $A P P / P S 1 /$ $\operatorname{tau}^{-1-}$ mice $(\mathbf{C}$ and $\mathbf{D})$ at 12 months of age. E: Stereological quantification of neurons in the Ammon's horn of hippocampus of $\tan ^{+/+}(n=4), \tan ^{-1}$ $(n=4), A P P / P S 1 / \tan ^{+/+}(n=4)$, and APP/PS1/tau ${ }^{-/-}$mice $(n=3)$. $A P P / P S 1 / \tan ^{+/+}$mice, but not $A P P / P S 1 / t^{-1} u^{-1}$ mice, show a neuronal loss compared to $\operatorname{tau}^{+/+}$mice. ${ }^{*} P<0.05$, Bonferroni post hoc test, two-way analysis of variance. F: Stereological quantification of neurons in the anterior horn of spinal cord of $\operatorname{tau}^{+/+}(n=3), \operatorname{tau}^{-/-}(n=7)$, APP/PS1/tau $^{+/+}(n=$ $3)$, and $A P P / P S 1 / \mathrm{tau}^{-1-}$ mice $(n=4)$. The neuronal density in the spinal cord differs by genotype ( $A P P / P S 1$ by tau interaction, $P<0.01$, two-way analysis of variance), and $A P P / P S 1 / \operatorname{tau}^{+/+}$mice have a lower neuronal density compared to all other genotypes. ${ }^{*} P<0.05$, Bonferroni post hoc test. G: Quantification of spine density in cortical neurons of $\operatorname{tau}^{+/+}(n=5)$, $\operatorname{tau}^{-/-}(n=5), A P P / P S 1 / t_{a u}^{+/+}(n=4)$, and APP/PS1/tau ${ }^{-/-}$mice $(n=4)$. $A P P / P S 1 / \mathrm{tau}^{+/+}$mice, but not $A P P / P S 1 / \mathrm{tau}^{-/-}$mice, show a decreased spine density compared to $\operatorname{tau}^{+/+}$mice. ${ }^{*} P<0.05$. Bonferroni post hoc test two-way analysis of variance. H: Mean number of spines along $30-\mu \mathrm{m}$ (bin size) segments of apical dendrite in the four genotypes. 

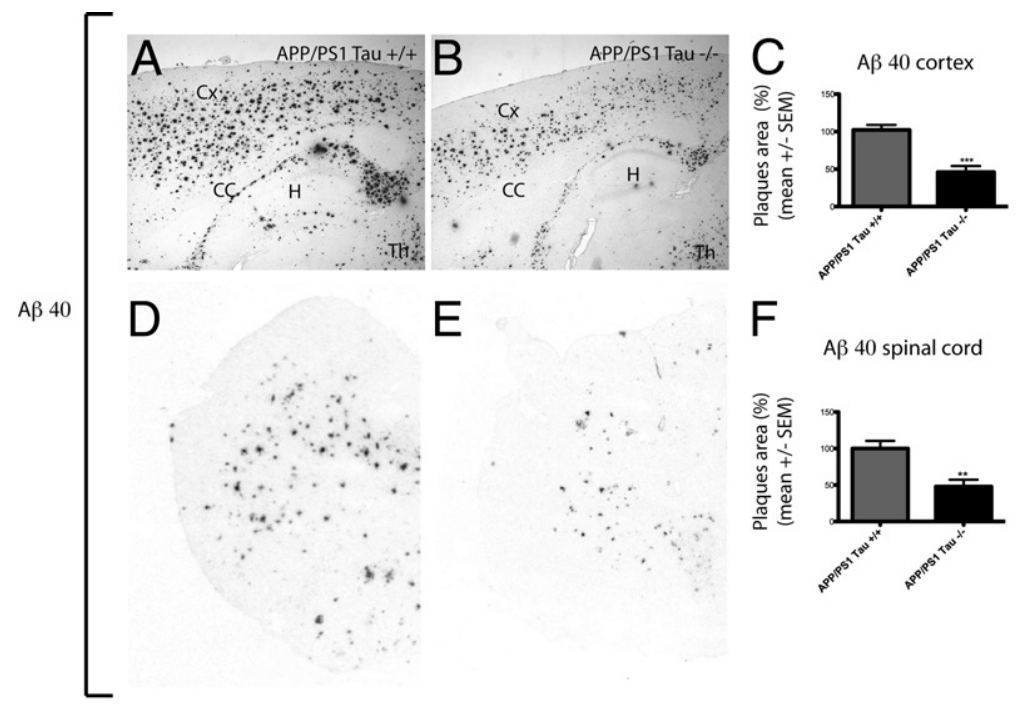
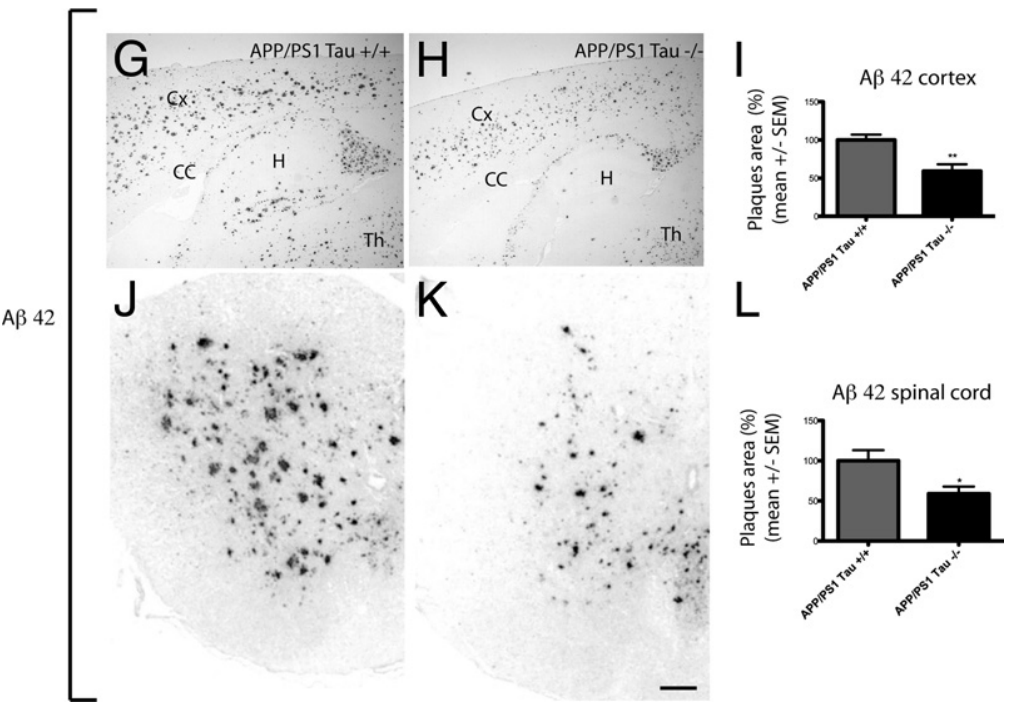

Figure 5. Amyloid plaque burden is lower in APP/PS1 $\mathrm{tau}^{-/-}$than in $A P P / P S 1 / \mathrm{tau}^{+/+}$mice. A-F: Immunolabeling of tissue sections of APP/PS1/tau ${ }^{+/+}(\mathbf{A}$ and $\mathbf{D}$ ) and APP/PS1 $\operatorname{tau}^{-1-}(\mathbf{B}$ and $\mathbf{E})$ 6-month-old mice with an antibody to $\mathrm{A} \beta 40$. The A $\beta 40$ plaque load in the cortex $(\mathbf{C})$ and the spinal cord $(\mathbf{F})$ is significantly lower in APP/PS1/tau ${ }^{-1-}$ mice $(n=5) \mathrm{com}-$ pared to $A P P / P S 1 / \tan ^{+/+}$mice $(n=3)$. G-L: Immunolabeling of tissue sections of $A P P / P S 1 / \mathrm{tan}^{+/+}(\mathbf{G}$ and $\mathbf{J})$ and $A P P / P S 1 /$ $\tan ^{-1-}(\mathbf{H}$ and $\mathbf{K}$ ) 6-month-old mice with an antibody to $\mathrm{A} \beta 42$. The $\mathrm{A} \beta 42$ plaque load in the cortex (I) and the spinal cord $(\mathbf{L})$ is significantly lower in $A P P / P S 1 /$ tau $^{-/-}$mice $(n=5)$ compared to $A P P / P S 1 /$ tau $^{+/+}$mice $(n=3) .{ }^{*} P<0.05,{ }^{* *} P<$ 0.01 , and ${ }^{* * *} P<0.001$ by Student's $t$-test. CC, corpus callosum; Cx, cortex; H, hippocampus; Th, thalamus. Scale bars: $200 \mu \mathrm{m}$ $(\mathbf{A}, \mathbf{B}, \mathbf{G}$, and $\mathbf{H}) ; 100 \mu \mathrm{m}(\mathbf{D}, \mathbf{E}, \mathbf{J}$, and $\mathbf{K})$. showed a significant reduction in spontaneous alternations by comparison with $\mathrm{tau}^{+/+}$mice. Spontaneous alternations were significantly higher in APP/PS1/tau ${ }^{-1-}$ mice than in APP/PS1/tau ${ }^{+/+}$mice and not different from $\mathrm{tau}^{+/+}$and $\mathrm{tau}^{-/-}$mice.

\section{Loss of Neurons and Synaptic Loss in APP/PS1/ tau $^{+/+}$Mice Is Rescued in APP/PS1/tau ${ }^{-/-}$Mice}

Neuronal loss in the hippocampus and the spinal cord was then assessed by stereology with the optical fractionator method in 12-month-old mice (Figure 4). The number of neurons in Ammon's horn of the hippocampus of APP/PS1/tau ${ }^{+/+}$mice, but not of APP/PS1/tau ${ }^{-/-}$ mice, was significantly reduced by comparison with tau $^{+/+}$(Figure 4E). In the anterior horn of spinal cord (Figure 4F), the density of neurons in APP/PS1/tau ${ }^{+/+}$ mice was reduced by $50 \%$ in comparison with $\operatorname{tau}^{+/+}$or $\mathrm{tau}^{-1-}$ mice and was significantly higher in APP/PS1/ $\mathrm{tau}^{-1-}$ mice.

We assessed the synaptic loss in APP/PS1/tau ${ }^{+/+}$and APP/PS1/tau ${ }^{-1-}$ mice by investigating by Western blot- ting the levels of the presynaptic marker synaptophysin and the postsynaptic marker PSD95 in 12-month-old mice. Mean brain synaptophysin and PSD95 levels were lower in APP/PS1/tau ${ }^{+/+}$and APP/PS1/tau ${ }^{-1-}$ mice than in $\mathrm{tau}^{+/+}$mice, but were not different between them (data not shown). We next analyzed the density of dendritic spines in Golgi-stained brain sections in 12-month-old mice. The mean spine density along a $150-\mu \mathrm{m}$ segment of primary apical dendrites of cortical neurons of APP/ $P S 1 / \mathrm{tau}^{+/+}$mice, but not of APP/PS1/tau ${ }^{-/-}$mice, was significantly lower than in $\operatorname{tau}^{+/+}$mice (Figure $4 \mathrm{G}$ ). In the first 30- $\mu \mathrm{m}$ segment, APP/PS1/tau ${ }^{+/+}$mice had a spine density significantly reduced in comparison with all other genotypes (Figure 4H).

\section{Amyloid Plaque Burden Is Lower in APP/PS1/ tau $^{-/-}$Than in APP/PS1/tau ${ }^{+/+}$Mice}

As reported previously, ${ }^{13}$ amyloid plaques were first detected with anti-A $\beta$ antibodies in young 2-month-old APP/ $P S 1 / \mathrm{tau}^{+/+}$mice in the subiculum and in deep cortical 
A
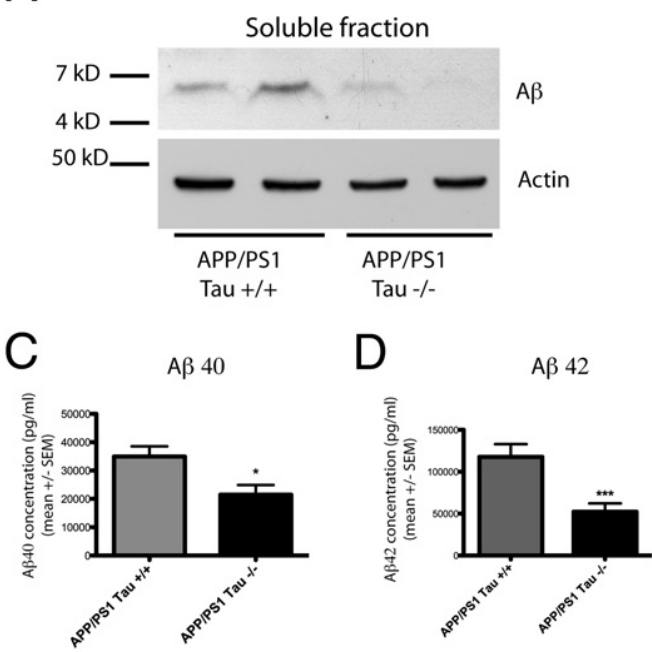

$\mathrm{F}$

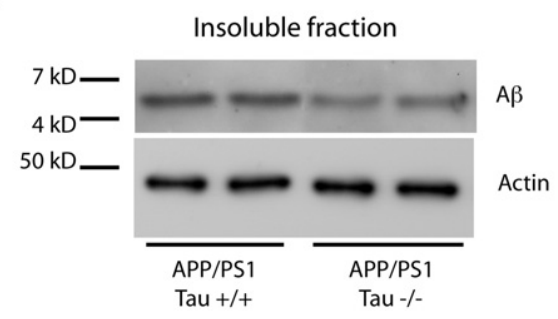

$\mathrm{H}$

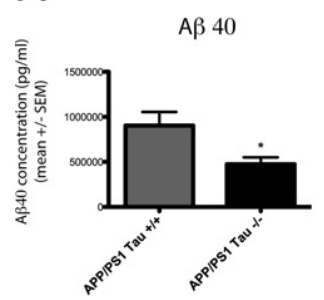

I

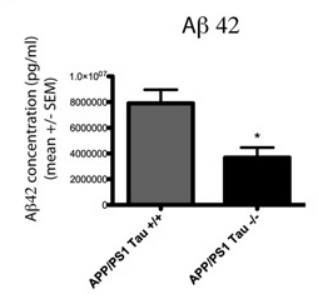

B

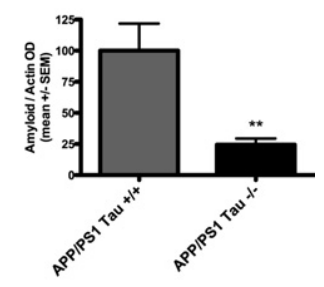

E

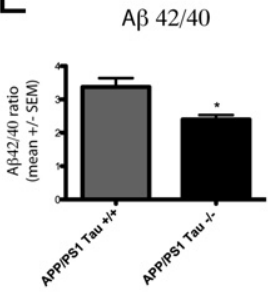

$\mathrm{G}$

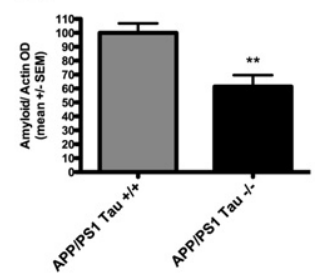

$J$

A $\beta 42 / 40$

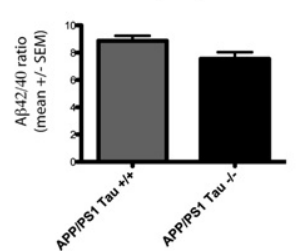

Figure 6. Levels of soluble and insoluble $\mathrm{A} \beta$ are lower in $A P P / P S 1 / \mathrm{tau}^{-/-}$mice than in $A P P / P S 1 / \tan ^{+/+}$mice. Analysis of $\mathrm{A} \beta$ in brain homogenates of $A P P / P S 1 / \operatorname{tau}^{+/+}$and APP/PS1/ tau $^{-1-}$ mice at 6 months of age. A-E: Analysis of A $\beta$ levels in RIPA-soluble fraction by Western blot $(n=7$ for each genotype) with the 6E10 antibody (A and B), and by ELISA ( $n=3$ for each genotype) for $\mathrm{A} \beta 40(\mathbf{C})$, for $\mathrm{A} \beta 42(\mathbf{D})$, and for the $\mathrm{A} \beta 42 / \mathrm{A} \beta 40$ ratio $(\mathbf{E})$. $\mathbf{F}-\mathbf{J}$ : Analysis of $\mathrm{A} \beta$ levels in RIPAinsoluble fraction by Western blot ( $n=7$ for each genotype) with the 6E10 antibody (F and $\mathbf{G})$, and by ELISA ( $n=3$ for each genotype) for $\mathrm{A} \beta 40(\mathbf{H})$, for $\mathrm{A} \beta 42(\mathbf{I})$, and for the $\mathrm{A} \beta 42$ ) $\mathrm{A} \beta 40$ ratio (J). A significant decrease of $\mathrm{A} \beta 40$ and $\mathrm{A} \beta 42$ is observed in the soluble and insoluble fractions in APP/PS1/ $\tan ^{-/-}$mice compared to $A P P / P S 1 /$ tau $^{+/+}$mice. The A $\beta 42 / 40$ ratio is significantly decreased in the soluble fraction and is generally decreased in the insoluble fraction in APP/PS1 tau $^{-1-}$ mice. Molecular weight markers: (A and F) $4 \mathrm{kDa}$ (insulin $\beta$ chain), $7 \mathrm{kDa}$ (aprotinin), $50 \mathrm{kDa}$ (alcohol dehydrogenase). ${ }^{*} P<0.05,{ }^{* *} P<0.01$, and ${ }^{* * *} P<0.001$ by Student's $t$-test.

layers, and progressed later in all cortical layers, in subcortical areas, and in the brainstem. Amyloid plaques were also detected in the spinal cord. Amyloid deposition tended to be lower in male than in female mice. A similar spatial pattern of amyloid deposition in the brain was observed in APP/PS1/tau ${ }^{-/-}$mice. Amyloid plaques, however, appeared less numerous in APP/PS1/tau ${ }^{-/-}$ mice at all investigated ages. The load of amyloid plaques in 6-month-old APP/PS1/tau ${ }^{+/+}$and APP/PS1/ tau $^{-1-}$ mice was then quantified by immunocytochemistry with antibodies to $A \beta 40$ and to $A \beta 42$ (Figure 5). The mean area covered by $A \beta 40$-positive (Figure $5, A-F)$ and A $\beta 42$-positive (Figure 5, G-L) plaques was significantly lower in the cortex and the spinal cord of APP/PS1/tau ${ }^{-1-}$ mice. We then calculated the density and the mean size of $A \beta 42-$ and $A \beta 40$-positive plaques in the cortex of 6-month-old mice. In APP/PS1/tau ${ }^{-/-}$mice, the density of $A \beta 42$-positive $\left(91 \pm 16\right.$ plaques $\left./ \mathrm{mm}^{2}\right)$ and $A \beta 40$-positive $\left(81 \pm 14\right.$ plaques $\left./ \mathrm{mm}^{2}\right)$ plaques was significantly lower in comparison with APP/PS1/tau ${ }^{+/+}$mice (157 \pm 17 plaques $/ \mathrm{mm}^{2}$ for $A \beta 42 ; 159 \pm 7$ plaques $/ \mathrm{mm}^{2}$ for $\left.A \beta 40\right)$ $(P<0.01$ for $A \beta 40$ and $P<0.05$ for $A \beta 42$, by Student's t-test). The mean size of $A \beta 42$-positive plaques was also significantly lower in APP/PS1/tau ${ }^{-1-}$ mice $\left(433 \pm 10 \mu \mathrm{m}^{2}\right)$ in comparison with APP/PS1/tau ${ }^{+/+}$mice $\left(528 \pm 35 \mu \mathrm{m}^{2}\right)$ ( $P<0.05$ by Student's $t$-test). The reduction of amyloid plaque burden in APP/PS1/tau ${ }^{-1-}$ mice was similarly observed when using Congo Red or thioflavin staining, indicating that this decrease did not result from a shift from fibrillar to diffuse $A \beta$ deposition.

Levels of Soluble and Insoluble A $\beta$ Are Lower in APP/PS1/tau ${ }^{-1-}$ Mice Than in APP/PS1/tau ${ }^{+/+}$

\section{Mice}

We next analyzed the levels of $A \beta$ in the brain and spinal cord of 6-month-old APP/PS1/tau ${ }^{+/+}$and APP/PS1/ $\mathrm{tau}^{-/-}$mice by immunoblotting with the $6 \mathrm{E} 10$ anti-A $\beta$ antibody (recognizing both $A \beta 40$ and $A \beta 42$ ) (Figure 6). The levels of $A \beta$ were analyzed in the RIPA soluble fractions (Figure 6, A-E) and in the RIPA insoluble fractions after formic acid extraction (Figure 6, F-J). The levels of 
total $A \beta$ in both the brain and the spinal cord were significantly lower in the soluble (Figure 6B) and insoluble (Figure 6G) fractions in APP/PS1/tau ${ }^{-/-}$mice, in comparison with APP/PS1/tau ${ }^{+/+}$mice. To determine whether this reduction concerned shorter and longer forms of $A \beta$, the levels of $A \beta 38, A \beta 40$, and $A \beta 42$ were then analyzed separately by enzyme-linked immunosorbent assay (ELISA) in the same fractions. By ELISA, A $\beta 38$ (data not shown), $A \beta 40$, and $A \beta 42$ levels were significantly lower in the brain and the spinal cord in the soluble (Figure $6, \mathrm{C}$ and $\mathrm{D}$ ) and insoluble (Figure $6, \mathrm{H}$ and I) fractions in APP/PS1/tau ${ }^{-1-}$ mice compared to APP/PS1/tau ${ }^{+/+}$ mice. Levels of $A \beta 42$ were higher than levels of $A \beta 40$ and $A \beta 38$, both in the soluble and in the insoluble fractions in both genotypes.

A

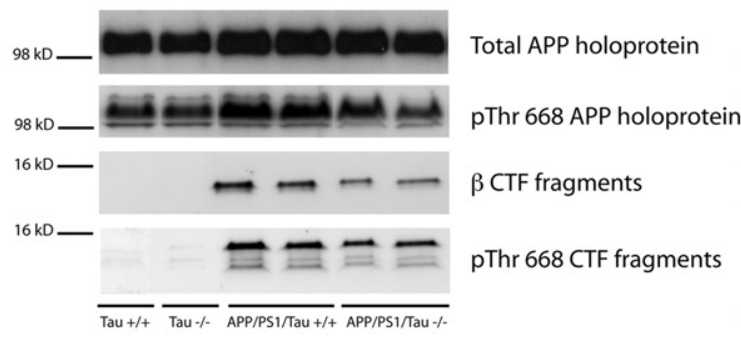

B
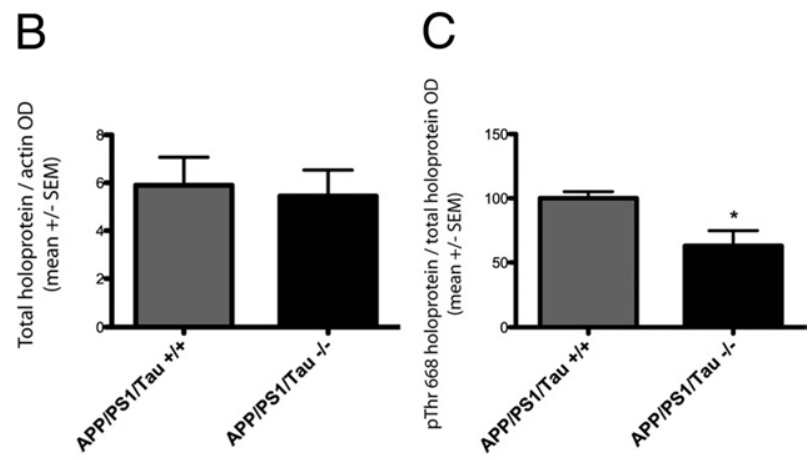

D

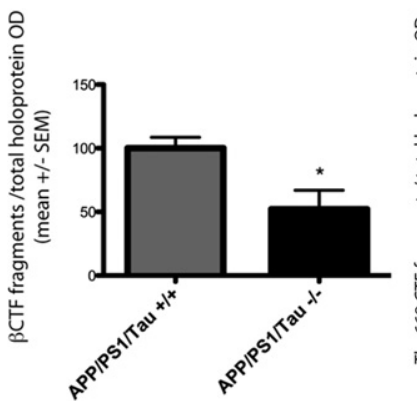

$\mathrm{E}$

Figure 7. Levels of APP $\beta$-CTFs and of phosphorylated Thr668 APP are lower in $A P P / P S 1 /$ tau $^{-/-}$than in APP/PS1/tau ${ }^{+/+}$mice. A: Western blot analysis of brain homogenates of $\operatorname{tau}^{+/+}, \mathrm{tau}^{-/-}, A P P / P S 1 / \mathrm{tau}^{+/+}$, and $A P P / P S 1 / t^{-1} u^{-1}$ mice at 6 months of age with the BR15 antibody recognizing APP holoprotein, with the APP668P antibody recognizing APP holoprotein and CTFs phosphorylated on Thr668, and with the 6E10 antibody recognizing $\beta$-CTFs. Molecular weight markers: $16 \mathrm{kDa}$ (lysozyme), $98 \mathrm{kDa}$ (bovine serum albumin). B-E: Densitometry analysis of levels of APP, pThr668 APP, and CTFs. Levels of APP holoprotein are similar in APP/PS1/tau ${ }^{+/+}(n=9)$ and $A P P / P S 1 /$ tau $^{-/-}(n=10)$ mice $(\mathbf{B})$, but levels of pThr668 APP (C), of $\beta$-CTFs (D), and of pThr668 CTFs (E) are lower in $A P P / P S 1 / t_{a}{ }^{-/}$mice. ${ }^{*} P<0.05,{ }^{* *} P<0.01$, and ${ }^{* * * *} P<0.001$ by Student's $t$-test.
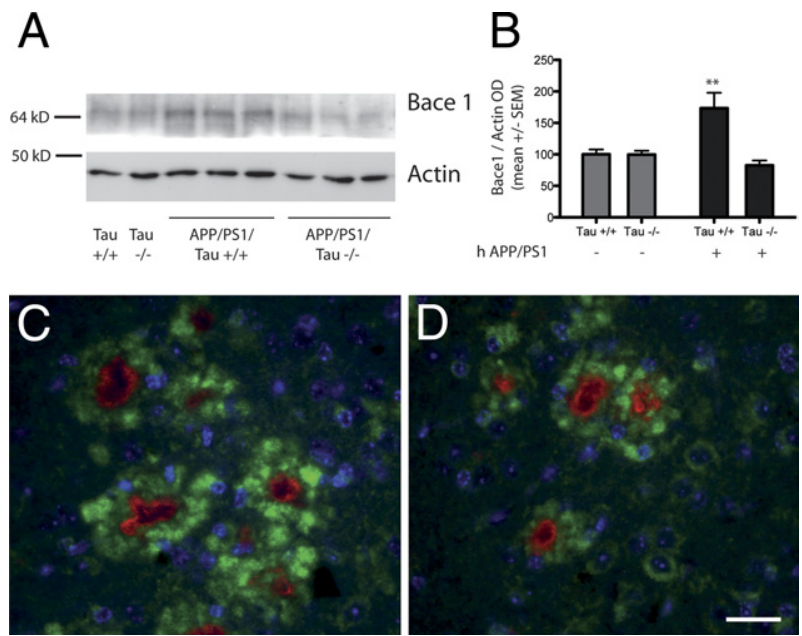

Figure 8. Levels of BACE1 are reduced in APP/PS1/tau ${ }^{-/-}$mice. A: Western blots of brain homogenates of $\operatorname{tau}^{+/+}$(lane 1), $\operatorname{tau}^{-/-}$(lane 2), APP/PS1 $\operatorname{tau}^{+/+}$(lanes 3-5), and APP/PS1/tau ${ }^{-/-}$mice (lanes 6-8) at 6 months of age with BACE1 and actin antibodies. BACE 1 migrates as a $70-\mathrm{kDa}$ main band. B: Densitometry analysis of BACE1 levels ( $n=7$ for each genotype). BACE1 levels differ by genotypes ( $A P P / P S 1$ by tau interaction, $P<0.01$, two-way analysis of variance) and are significantly higher in $A P P / P S 1 / \operatorname{tau}^{+/+}$mice compared to other genotypes. ${ }^{* *} P<0.01$, Bonferroni post hoc test. $\mathbf{C}$ and $\mathbf{D}$ : Double immunohistochemical labeling (cortex) with the anti-BACE1 antibody (green) and the anti-A $\beta$ antibody (red) in an APP/PS1/tau ${ }^{+/+}(\mathbf{C})$ and an $A P P / P S 1 / t^{-1} u^{-}$(D) mouse. A BACE1-positive annulus surrounds the amyloid core of plaques. Scale bar $=15 \mu \mathrm{m}$.

Because an increased ratio of $A \beta 42$ to $A \beta 40$ favors the aggregation of $A \beta$, we determined the $A \beta 42 / A \beta 40$ ratios based on levels determined by ELISA in APP/PS1/tau ${ }^{+/+}$ and APP/PS1/tau ${ }^{-1-}$ mice. A significant decrease of the $A \beta 42 / A \beta 40$ ratio was observed in the soluble fraction (Figure 6E) in the brain and the spinal cord of APP/PS1/ tau $^{-\prime-}$ mice. A similar tendency was also observed in the insoluble fraction (Figure 6J).

\section{Levels of APP $\beta$-C-Terminal Fragments and of BACE1 Are Decreased in APP/PS1/tau ${ }^{-1-}$ Mice}

Because a reduction of $A \beta$ might result from reduced $\beta$-secretase cleavage of APP by BACE1, the levels of $\beta$-C-terminal fragments ( $\beta$-CTFs) of APP were analyzed in the brain and spinal cord of 6-month-old APP/PS1/tau ${ }^{+/+}$ and $A P P / P S 1 / t^{-1}{ }^{-1}$ mice by immunoblotting (Figure 7A). The steady-state levels of $\beta$-CTFs normalized to APP holoprotein were significantly reduced in the brains (Figure 7D) and in the spinal cords (not shown) of APP/PS1/ $\mathrm{tau}^{-1-}$ mice. APP phosphorylation at Thr668 has been reported to increase $A \beta$ generation. ${ }^{20,24}$ The levels of phosphorylated APP holoprotein (Figure 7C) and of phosphorylated CTFs (Figure 7E) normalized to total APP holoprotein were significantly reduced in the brains and in the spinal cord of APP/PS1/tau ${ }^{-1-}$ mice.

BACE1 levels have been reported to be increased in $5 x F A D$ mice. ${ }^{25}$ We analyzed the levels of BACE1 in the brain of APP/PS1/tau ${ }^{+/+}$and APP/PS1/tau ${ }^{-/-}$mice by Western blotting: BACE1 levels were significantly lower in APP/PS1/tau ${ }^{-1-}$ mice (Figure 8, A and B). As reported earlier, we observed that BACE1 immunoreactivity was increased in a positive annulus surrounding the amyloid 
A
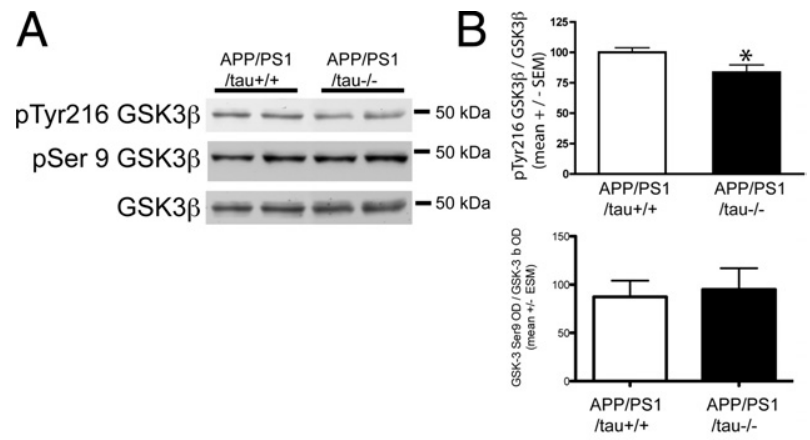

C

IP-PS1

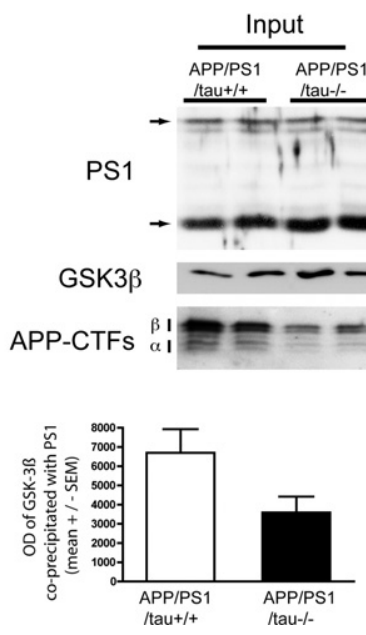

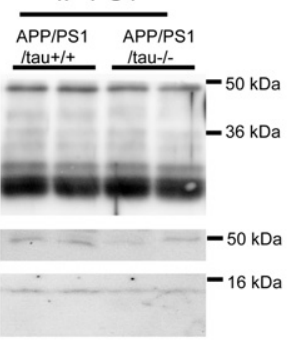

E

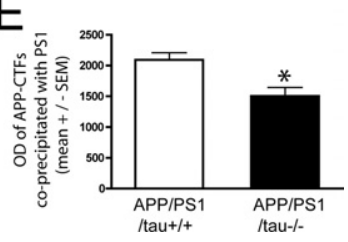

Figure 9. pTyr216 GSK-3 $\beta$ and PS1/GSK-3 $\beta$, PS1/APP-CTFs complexes are less abundant in $A P P / P S 1 /$ tau $^{-/-}$mice. A: Western blot analysis of brain homogenates of $A P P / P S 1 / \mathrm{tau}^{+/+}$and $A P P / P S 1 / \mathrm{tau}^{-/-}$mice with the antipTyr216 GSK-3 $\beta$, anti-pSer9 GSK-3 $\beta$ and anti-GSK-3 $\beta$ (TPK1) antibodies in 12 -month-old mice. B: Densitometry analysis ( $n=7$ for each genotype) of levels of pTyr216 GSK-3 $\beta$ and pSer9 GSK-3 normalized to GSK-3 $\beta$. Levels of pTyr216 GSK-3 $\beta$ are significantly reduced in $A P P / P S 1 / t_{a}{ }^{-1}$ mice. C: PS1 was immunoprecipitated from brain homogenates (input) of APP/PS1 $\mathrm{tau}^{+/+}$and $\mathrm{APP} / \mathrm{PS} 1 / \mathrm{tau}^{-/-}$mice, and immunoprecipitates (IP-PS1) were analyzed by Western blotting with the PS1 antibody (SB129), the GSK-3 $\beta$ antibody (TPK1), and the APP antibody (C17). The arrows point to PS1 holoprotein and N-terminal fragments, respectively. D and E: Densitometry analysis ( $n=3$ for each genotype) of levels of GSK-3 $\beta$ (D) and APP-CTFs (E) in PS1 immunoprecipitates. GSK- $3 \beta$ and APP-CTFs are co-immunoprecipitated with PS1 but are less abundant in $A P P / P S 1 / \operatorname{tau}^{-1-}$ mice. ${ }^{*} P<0.05$ by Student's $t$-test.

core of plaques in both APP/PS1/tau ${ }^{+/+}$and APP/PS1/ tau $^{-1-}$ mice (Figure 8, C and D). ${ }^{25}$ Finally, because reduction of $\beta$-secretase cleavage of APP might be associated with a relatively increased $\alpha$-secretase cleavage, we calculated the ratio of $\alpha$-CTFs (resulting from $\alpha$-secretase cleavage) to $\beta$-CTFs (using the BR15 anti-Cter APP antibody): this ratio was slightly increased from $1.00 \pm$ 0.06 to $1.14 \pm 0.07$ when comparing APP/PS1/tau $u^{+/+}$to $A P P / P S 1 / \mathrm{tau}^{-1-}$ mice. The levels of A $\beta$ protease insulindegrading enzyme and transthyretin were unchanged in APP/PS1/tau ${ }^{-\prime-}$ mice (data not shown).

\section{Levels of PhosphoY216 GSK-3 $\beta$ and of PS1/ GSK-3 $\beta$ /APP-CTF Complexes Are Lower in APP/PS1/tau ${ }^{-1-}$ Mice}

GSK-3 $\beta$ activity might be modulated by PS1 and has been involved in APP processing. Total levels of GSK-3 $\beta$

and of inactive pSer9 GSK-3 $\beta$ were unchanged in APP/ PS1/tau ${ }^{-/-}$mice, but levels of active pTyr216 GSK-3 $\beta$ (normalized to total GSK-3 $\beta$ ) were significantly reduced in these mice (Figure 9, A and B). PS1 forms a complex with GSK- $3 \beta^{11}$ and APP, and we analyzed these complexes after immunoprecipitation of PS1 from brain homogenates of APP/PS1/tau ${ }^{+/+}$and APP/PS1/tau ${ }^{-/-}$ mice (Figure 9C). GSK-3 $\beta$ was present in PS1 immunoprecipitates in both genotypes but was reduced in APP/ $P S 1 /$ tau $^{-1-}$ mice (Figure 9D). $\beta$-CTFs were also immunoprecipitated with PS1 and their levels significantly reduced in APP/PS1/tau ${ }^{-/-}$mice (Figure 9E).

\section{APP/PS1/tau ${ }^{+/+}$and APP/PS1/tau ${ }^{-/-}$Mice Both Develop Neuritic Plaques and a Glial Reaction}

We next compared the abnormal neuritic components associated with amyloid deposits in both genotypes by immunocytochemistry with antibodies to cathepsin B and by transmission electron microscopy. Cathepsins are lysosomal proteases that have been observed to be concentrated in autophagolysosomes accumulating in dystrophic neurites in senile plaques in Alzheimer disease. ${ }^{26}$ In both APP/PS1/tau ${ }^{+/+}$and APP/PS1/tau ${ }^{-/-}$6-monthold mice, the vast majority of amyloid deposits were similarly associated with cathepsin B-positive dystrophic neurites, indicating that tau expression was not necessarily for the formation of these abnormal neurites (see Supplemental Figure S1, A and B, at http://ajp.amjpathol. org). In electron microscopy (see Supplemental Figure S1, C and D, at http://ajp.amjpathol.org), dystrophic neurites showed in both genotypes accumulations of autophagic vacuoles, multivesicular bodies, and mitochondria, as reported in other APP/PS1 mice. ${ }^{23}$ We also investigated the astroglial and microglial reaction in the cortex, the hippocampus, and the spinal cord by immunohistochemistry with anti-GFAP and anti-lba1 antibodies. Reactive astrocytes and microglial cells were similarly associated with amyloid deposits in both genotypes (data not shown).

\section{Discussion}

To assess the effect of tau deletion on the deficient phenotype induced by mutant APP and PS1, we generated a new transgenic model expressing both mutant APP and PS1 proteins, in absence of any tau proteins. APP/PS1/ $\mathrm{tau}^{+/+}$mice showed a deficit in working memory at 6 months of age, and we observed a complete rescue of this cognitive deficit in APP/PS1/tau ${ }^{-/-}$mice. APP/PS1/ $\mathrm{tau}^{+/+}$mice had a reduced survival compared to $\mathrm{tau}^{+/+}$ mice, and this reduced survival was not observed in APP/PS1/tau ${ }^{-/-}$mice. Aged APP/PS1 mice also had a motor deficit that was completely rescued in APP/PS1/ $\mathrm{tau}^{-\prime-}$ mice. Thus tau deletion is effective in rescuing, not only reduced survival and cognitive deficits, but also motor deficits. A rescue of cognitive deficits by tau deletion was also observed previously in two models expressing mutant APP alone and deleted for tau, ${ }^{3,4,9}$ but not in 
all. ${ }^{10}$ This effect of tau deletion on several kinds of deficient behavioral phenotypes must result from an effect targeting different neuronal populations, and suggests a more general protective effect of tau deletion than previously suggested.

Aged APP/PS1/tau ${ }^{+/+}$(5xFAD) mice have been reported to have a loss of large pyramidal cortical neurons ${ }^{13,27}$; by using an unbiased stereological method, we observed that these aged APP/PS1/tau ${ }^{+/+}$mice also have a loss of pyramidal neurons in the hippocampus. In addition, we document a loss of neurons in the anterior spinal cord, probably linked to the development of the motor deficits in the aged APP/PS1/tau ${ }^{+/+}$mice. Interestingly, we observed that tau deletion rescued this loss of neurons in the hippocampus and decreased the loss in the spinal cord. In previous studies in mice expressing only mutant APP, tau deletion was found to protect against early mortality, excitotoxicity, and spontaneous epileptiform activity, ${ }^{3,4,9}$ but an effect on neuronal death was not demonstrated: one study ${ }^{3}$ used hAPPJ20 mice that do not show substantial neuronal loss, ${ }^{28}$ and the other study ${ }^{4}$ did not assess changes in neuronal loss using APP23 mice. ${ }^{29}$ Spine loss in APP/PS1/tau ${ }^{+/+}$mice was also partially rescued in APP/PS1/tau ${ }^{-1-}$ mice.

An interesting finding of this study is that tau deletion also decreases amyloid burden in APP/PS1 mice. This decrease, roughly of $50 \%$, concerns both the extent of extracellular deposition of $A \beta$ in amyloid plaques as estimated by morphological measurements, and the levels of soluble and insoluble $A \beta$ as estimated by immunoblotting and ELISA measurements. $A \beta$ reduction did not result from reduced expression of mutant APP or PS1 in APP/PS1/tau ${ }^{-/-}$mice because APP and PS1 levels were similar to those seen in APP/PS1/tau ${ }^{+/+}$mice. Also, the levels of $A \beta$ protease insulin-degrading enzyme and transthyretin were unchanged in APP/PS1/tau ${ }^{-/-}$mice. A $\beta$ reduction in APP/PS1/tau ${ }^{-1-}$ mice, however, was associated with a reduction of steady-state levels of $\beta$-CTFs. APP phosphorylation at Thr668 has been reported to facilitate BACE1 cleavage, ${ }^{24}$ and $\beta$-CTF phosphorylation was reported to facilitate $\gamma$-secretase cleavage. ${ }^{20}$ Levels of phosphorylated APP and $\beta$-CTFs were reduced in APP/PS1/tau ${ }^{-/-}$mice. Also, levels of BACE1 were reduced in the APP/PS1/tau ${ }^{-\prime-}$ mice compared to APP/ $P S 1 /$ tau $^{+/+}$mice in which an increase in BACE1 levels was previously observed. ${ }^{25}$ All together, this suggests that tau deletion impaired $\beta$-secretase cleavage of APP in APP/PS1/tau ${ }^{-/-}$mice. A modification of BACE1 accessibility to APP at the plasma membrane in lipid rafts or in early endosomes and/or trafficking of BACE1 between these two compartments might conceivably be disturbed by tau deletion affecting actin/clathrin-mediated endocytosis. tau deletion was also recently reported to affect APP trafficking to the neuronal surface. ${ }^{30}$

We observed a significant decrease of the active form of GSK-3 $\beta$ (pY216) in APP/PS1/tau ${ }^{-/-}$mice that might have played a role in reduction of $A \beta$ levels, because a reduction of GSK- $3 \alpha^{31}$ and GSK- $3 \beta^{32}$ activities were reported to reduce A $\beta$ levels in APP mice, although the role of GSK-3 in modulation of APP processing is still a matter of investigation. ${ }^{33,34}$ Con- versely, $A \beta$ has been reported to induce GSK-3 $\beta$ activation, ${ }^{7,35}$ and reduction of $A \beta$ levels might also reduces GSK-3 $\beta$ activation on its own.

We also observed a reduced association of GSK-3 $\beta$ with PS1 in APP/PS1/tau ${ }^{-1-}$ mice. Because GSK-3 $\beta-$ mediated phosphorylation of PS1 inhibits the PI3/AKT activation of cell survival signaling, ${ }^{36}$ reduction of GSK$3 \beta-P S 1$ association in APP/PS1/tau ${ }^{-1-}$ mice could reduce the PS1-mediated inhibition of cell survival, rescuing neuronal cell death observed in these mice. tau deletion was also reported to reduce GSK-3 $\beta$-induced hippocampal neurodegeneration. ${ }^{37}$

In addition to a reduction of $A \beta$, tau deletion in APP/ $P S 1 / \mathrm{tau}^{-/-}$mice led to a decrease of the $A \beta 42 / A \beta 40$ ratio in comparison with APP/PS1 mice. The APP/PS1 (5xFAD) model used in this study expresses a mutant APP bearing three FAD mutations (Swedish, Florida, and London), and a mutant PS1 bearing two FAD mutations. The Swedish mutation increases the production of total $\mathrm{A} \beta$, and the Florida, the London, and the PS1 mutations increase the production of $A \beta 42$. The combination of these mutations is additive and leads to the production of high levels of $A \beta 42 .{ }^{13}$ High $A \beta 42 / A \beta 40$ ratios promote plaque nidus formation, which are more numerous in APP/PS1 (5xFAD) mice than in APP mice, such as Tg2576 expressing only the APPsw mutation. ${ }^{13}$ The lower density of amyloid plaques and the smaller size of $A \beta 42$ positive plaques in APP/PS1/tau ${ }^{-/-}$mice is compatible with less nucleation nidus and slower growth due to a reduced $A \beta 42 / A \beta 40$ ratio. Interestingly, although tau deletion reduced the amyloid load, amyloid deposits were systematically associated with dystrophic neurites in both APP/PS1/tau ${ }^{+/+}$and APP/PS1/tau ${ }^{-/-}$mice, suggesting that tau expression was not necessarily for the formation of these abnormal processes.

Like other APP transgenic lines, ${ }^{3,4}$ APP/PS1/tau ${ }^{+/+}$ mice in our study exhibited early mortality and a higher frequency of sudden death. Many mouse AD models exhibit epileptic activity that might explain reported sudden death in APP mice. ${ }^{38,39}$ Tau reduction might reduce this mortality by mechanisms associated with reduced sensitivity to excitotoxicity, but also by reducing $A \beta$ load as observed in the present study.

Improved survival of APP/PS1/tau ${ }^{-/-}$mice was paralleled by rescue of motor deficit, neuronal loss, decreased spine density, and by decreased GSK- $3 \beta$ activity, compared to APP/PS1/tau ${ }^{+/+}$mice. These improved biological parameters might increase survival by themselves. Conversely, improved survival, eg, due to less $A \beta$ load and toxicity, could also improve these biological parameters.

$A \beta$ levels and amyloid plaque burden were not observed to be affected in mice expressing only mutant APP ${ }^{28,29}$ crossed with tau ${ }^{-1-}$ mice, ${ }^{3,4}$ although $A \beta$ levels were observed to be increased in another study. ${ }^{10} \mathrm{tau}^{-/-}$ mice in these studies were of different origin, ${ }^{14,40}$ but we used the same $\mathrm{tau}^{-1-}$ line ${ }^{14}$ as in one of the previous studies, ${ }^{4}$ suggesting that our observation of decreased amyloid burden in APP/PS1 mice was not due to the use of a different genetic background associated with tau deletion, but rather to the presence of a mutant PS1. A 
modification of APP processing induced by tau deletion could also conceivably result from changes in the interaction between the two proteins. APP and tau have been reported to interact with each other. ${ }^{41}$ Some antibodies to APP have been reported to label neurofibrillary tangles and isolated paired helical filaments, ${ }^{42-46}$ and tau enhances the formation of amyloid fibrils. ${ }^{47}$

Thus, tau deletion might prevent $A \beta$ toxicity by several mechanisms. As reported previously in APP mice, this includes control of neuronal excitability, alterations in Fyn subcellular localization, absence of generation of tau neurotoxic fragments, $A \beta$-induced deficits in axonal transport, and decreased microtubule stability. ${ }^{48,49}$ Here, we report an additional mechanism in APP/PS1 mice, in which tau deletion was found to reduce amyloidogenic processing of APP.

\section{Acknowledgments}

We thank Dr. Robert Vassar (Northwestern University, Chicago, IL) for providing the Tg6799 APP/PS1 mice, Drs. Nicolas Sergeant and Luc Buée (INSERM U837, France) for providing the 2061 and 2104 APP antibodies, and Dr. Christine Van Broeckhoven (University of Antwerp, Belgium) for providing the SB129 PS1 antibody.

\section{References}

1. Rapoport M, Dawson HN, Binder LI, Vitek MP, Ferreira A: Tau is essential to $\beta$-amyloid-induced neurotoxicity. Proc Natl Acad Sci U S A 2002, 99:6364-6369

2. King ME, Kan HM, Baas PW, Erisir A, Glabe CG, Bloom GS: Taudependent microtubule disassembly initiated by prefibrillar beta-amyloid. J Cell Biol 2006, 175:541-546

3. Roberson ED, Scearce-Levie K, Palop JJ, Yan FR, Cheng IH, Wu T, Gerstein H, Yu GQ, Mucke L: Reducing endogenous tau ameliorates amyloid beta-induced deficits in an Alzheimer's disease mouse model. Science 2007, 316:750-754

4. Ittner LM, Ke YD, Delerue F, Bi M, Gladbach A, van Eersel J, Wolfing H, Chieng BC, Christie MJ, Napier IA, Eckert A, Staufenbiel M, Hardeman E, Gotz J: Dendritic function of tau mediates amyloid-beta toxicity in Alzheimer's disease mouse models. Cell 2010, 142:387397

5. Walsh DM, Klyubin I, Fadeeva JV, Cullen WK, Anwyl R, Wolfe MS, Rowan MJ, Selkoe DJ: Naturally secreted oligomers of amyloid beta protein potently inhibit hippocampal long-term potentiation in vivo. Nature 2002, 416:535-539

6. Shipton OA, Leitz JR, Dworzak J, Acton CEJ, Tunbridge EM, Denk F, Dawson HN, Vitek MP, Wade-Martins R, Paulsen O, Vargas-Caballero $\mathrm{M}$ : Tau protein is required for amyloid beta-induced impairment of hippocampal long-term potentiation. J Neurosci 2011, 31:1688-1692

7. Jo J, Whitcomb DJ, Olsen KM, Kerrigan TL, Lo SC, Bru-Mercier G, Dickinson B, Scullion S, Sheng M, Collingridge G, Cho K: Abeta(1-42) inhibition of $L T P$ is mediated by a signaling pathway involving caspase-3. Akt1 and GSK-3beta, Nat Neurosci 2011, 14:545-547

8. Vossel KA, Zhang K, Brodbeck J, Daub AC, Sharma P, Finkbeiner S, Cui B, Mucke L: Tau reduction prevents Abeta-induced defects in axonal transport. Science 2010, 330:198

9. Roberson ED, Halabisky B, Yoo JW, Yao J, Chin J, Yan F, Wu T, Hamto P, Devidze N, Yu GQ, Palop JJ, Noebels JL, Mucke L: Amyloid-\{beta\}/Fyn-induced synaptic. Network, and cognitive impairments depend on tau levels in multiple mousemodels of Alzheimer's disease, J Neurosci 2011, 31:700-711

10. Dawson HN, Cantillana V, Jansen M, Wang H, Vitek MP, Wilcock DM, Lynch JR, Laskowitz DT: Loss of tau elicits axonal degeneration in a mouse model of Alzheimer's disease. Neuroscience 2010, 169:516531
11. Takashima A, Murayama M, Murayama O, Kohno T, Honda T, Yasutake K, Nihonmatsu N, Mercken M, Yamaguchi H, Sugihara S, Wolozin B: Presenilin 1 associates with glycogen synthase kinase- $3 \beta$ and its substrate tau. Proc Natl Acad Sci U S A 1998, 95:9637-9641

12. Baki L, Shioi J, Wen P, Shao ZP, Schwarzman A, Gama-Sosa M, Neve R, Robakis NK: PS1 activates PI3K thus inhibiting GSK-3 activity and tau overphosphorylation: effects of FAD mutations. EMBO J 2004, 23:2586-2596

13. Oakley H, Cole SL, Logan S, Maus E, Shao P, Craft J, GuillozetBongaarts A, Ohno M, Disterhoft J, Van Eldik L, Berry R, Vassar R: Intraneuronal beta-amyloid aggregates, neurodegeneration, and neuron loss in transgenic mice with five familial Alzheimer's disease mutations: potential factors in amyloid plaque formation. J Neurosci 2006, 26:10129-10140

14. Tucker KL, Meyer M, Barde YA: Neurotrophins are required for nerve growth during development. Nat Neurosci 2001, 4:29-37

15. Ando K, Leroy K, Heraud C, Yilmaz Z, Authelet M, Suain V, De Decker $\mathrm{R}$, Brion JP: Accelerated human mutant tau aggregation by knocking out murine tau in a transgenic mouse model. Am J Pathol 2011, 178:803-816

16. Leroy K, Bretteville A, Schindowski K, Gilissen E, Authelet M, De Decker R, Yilmaz Z, Buee L, Brion JP: Early axonopathy preceding neurofibrillary tangles in mutant tau transgenic mice. Am J Pathol 2007, 171:976-992

17. Leroy K, Ando K, Heraud C, Yilmaz Z, Authelet M, Boeynaems JM, Buee L, De Decker R, Brion JP: Lithium treatment arrests the development of neurofibrillary tangles in mutant tau transgenic mice with advanced neurofibrillary pathology. J Alzheimers Dis 2010, 19:705719

18. Brion JP, Hanger DP, Bruce MT, Couck AM, Flament-Durand J, Anderton BH: Tau in Alzheimer neurofibrillary tangles. N- and C-terminal regions are differentially associated with paired helical filaments and the location of a putative abnormal phosphorylation site, Biochem J 1991, 273 (Pt 1):127-133

19. Philippe B, Brion JP, Macq AF, Octave JN: A new monoclonal antibody against the anionic domain of the amyloid precursor protein of Alzheimer's disease. Neuroreport 1993, 5:289-292

20. Vingtdeux V, Hamdane M, Gompel M, Begard S, Drobecq H, Ghestem A, Grosjean ME, Kostanjevecki V, Grognet P, Vanmechelen E, Buee L, Delacourte A, Sergeant N: Phosphorylation of amyloid precursor carboxy-terminal fragments enhances their processing by a gamma-secretase-dependent mechanism. Neurobiol Dis 2005, 20 625-637

21. Hendriks L, De Jonghe C, Lubke U, Woodrow S, Vanderhoeven I, Boons J, Cras P, Martin JJ, Van Broeckhoven C: Immunoreactivity of presenilin-1 and tau in Alzheimer's disease brain. Exp Neurol 1998 149:341-348

22. Best JD, Jay MT, Otu F, Ma J, Nadin A, Ellis S, Lewis HD, Pattison C, Reilly M, Harrison T, Shearman MS, Williamson TL, Atack JR: Quantitative measurement of changes in amyloid-beta(40) in the rat brain and cerebrospinal fluid following treatment with the gamma-secretase inhibitor LY-411575 [N2-[(2S)-2-(3,5-difluorophenyl)-2-hydroxyethanoyl]-N1-[(7S)-5-methyl-6-ox o-6,7-dihydro-5H-dibenzo[bd]azepin-7-yl]-L-alaninamide]. J Pharmacol Exp Ther 2005, 313: 902-908

23. Boutajangout A, Authelet M, Blanchard V, Touchet N, Tremp G, Pradier L, Brion JP: Characterisation of cytoskeletal abnormalities in mice transgenic for wild-type human tau and familial Alzheimer's disease mutants of APP and presenilin-1. Neurobiol Dis 2004, 15: $47-60$

24. Lee MS, Kao SC, Lemere CA, Xia W, Tseng HC, Zhou Y, Neve R, Ahlijanian MK, Tsai LH: APP processing is regulated by cytoplasmic phosphorylation. J Cell Biol 2003, 163:83-95

25. Zhao J, Fu Y, Yasvoina M, Shao P, Hitt B, O'Connor T, Logan S, Maus E, Citron M, Berry R, Binder L, Vassar R: Beta-site amyloid precursor protein cleaving enzyme 1 levels become elevated in neurons around amyloid plaques: implications for Alzheimer's disease pathogenesis. J Neurosci 2007, 27:3639-3649

26. Nixon RA, Wegiel J, Kumar A, Yu WH, Peterhoff C, Cataldo A, Cuervo AM: Extensive involvement of autophagy in Alzheimer disease: an immuno-electron microscopy study. J Neuropathol Exp Neurol 2005, 64:113-122

27. Jawhar S, Trawicka A, Jenneckens C, Bayer TA, Wirths O: Motor deficits, neuron loss, and reduced anxiety coinciding with axonal 
degeneration and intraneuronal Abeta aggregation in the 5XFAD mouse model of Alzheimer's disease, Neurobiol Aging 2012, 33:196 e129-e140

28. Mucke L, Masliah E, Yu GQ, Mallory M, Rockenstein EM, Tatsuno G, Hu K, Kholodenko D, Johnson-Wood K, McConlogue L: High-level neuronal expression of $\mathrm{Ab}_{1-42}$ in wild-type human amyloid protein precursor transgenic mice: synaptotoxicity without plaque formation. J Neurosci 2000, 20:4050-4058

29. Sturchler-Pierrat C, Abramowski D, Duke M, Wiederhold KH, Mistl C, Rothacher S, Ledermann B, Burki K, Frey P, Paganetti PA, Waridel C, Calhoun ME, Jucker M, Probst A, Staufenbiel M, Sommer B: Two amyloid precursor protein transgenic mouse models with Alzheimer disease-like pathology. Proc Natl Acad Sci U S A 1997, 94:1328713292

30. Lei P, Ayton S, Finkelstein DI, Spoerri L, Ciccotosto GD, Wright DK, Wong BX, Adlard PA, Cherny RA, Lam LQ, Roberts BR, Volitakis I, Egan GF, McLean CA, Cappai R, Duce JA, Bush Al: Tau deficiency induces parkinsonism with dementia by impairing APP-mediated iron export. Nat Med 2012, 18:291-295

31. Phiel CJ, Wilson CA, Lee VM, Klein PS: GSK-3alpha regulates production of Alzheimer's disease amyloid-beta peptides. Nature 2003 423:435-439

32. Su Y, Ryder J, Li B, Wu X, Fox N, Solenberg P, Brune K, Paul S, Zhou Y, Liu F, Ni B: Lithium, a common drug for bipolar disorder treatment, regulates amyloid-beta precursor protein processing. Biochemistry 2004, 43:6899-6908

33. Feyt C, Kienlen-Campard P, Leroy K, N'Kuli F, Courtoy PJ, Brion JP, Octave JN: Lithium chloride increases the production of amyloid-beta peptide independently from its inhibition of glycogen synthase kinase 3. J Biol Chem 2005, 280:33220-33227

34. Jaworski T, Dewachter I, Lechat B, Gees M, Kremer A, Demedts D, Borghgraef P, Devijver H, Kugler S, Patel S, Woodgett JR, Van Leuven F: GSK-3alpha/beta kinases and amyloid production in vivo. Nature 2011, 480:E4-E5; discussion E6

35. Terwel D, Muyllaert D, Dewachter I, Borghgraef P, Croes S, Devijver $\mathrm{H}$, Van Leuven F: Amyloid activates GSK-3 beta to aggravate neuronal tauopathy in bigenic mice. Am J Pathol 2008, 172:786-798

36. Uemura K, Kuzuya A, Shimozono Y, Aoyagi N, Ando K, Shimohama S, Kinoshita A: GSK3 beta activity modifies the localization and function of presenilin 1. J Biol Chem 2007, 282:15823-15832

37. Gomez de Barreda E, Perez M, Gomez Ramos P, de Cristobal J, Martin-Maestro P, Moran A, Dawson HN, Vitek MP, Lucas JJ, Hernandez F, Avila J: Tau-knockout mice show reduced GSK3-induced hippocampal degeneration and learning deficits. Neurobiol Dis 2010, $37: 622-629$
38. Minkeviciene R, Rheims S, Dobszay MB, Zilberter M, Hartikainen J, Fulop L, Penke B, Zilberter Y, Harkany T, Pitkanen A, Tanila H: Amyloid beta-induced neuronal hyperexcitability triggers progressive epilepsy. J Neurosci 2009, 29:3453-3462

39. Palop JJ, Chin J, Roberson ED, Wang J, Thwin MT, Bien-Ly N, Yoo J, Ho KO, Yu GQ, Kreitzer A, Finkbeiner S, Noebels JL, Mucke L: Aberrant excitatory neuronal activity and compensatory remodeling of inhibitory hippocampal circuits in mouse models of Alzheimer's disease. Neuron 2007, 55:697-711

40. Dawson HN, Ferreira A, Eyster MV, Ghoshal N, Binder LI, Vitek MP: Inhibition of neuronal maturation in primary hippocampal neurons from tau deficient mice. J Cell Sci 2001, 114:1179-1187

41. Smith MA, Siedlak SL, Richey PL, Mulvihill P, Ghiso J, Frangione B, Tagliavini F, Giaccone G, Bugiani O, Praprotnik D, et al.: Tau protein directly interacts with the amyloid beta-protein precursor: implications for Alzheimer's disease. Nat Med 1995, 1:365-369

42. Yamaguchi $H$, Ishiguro K, Shoji M, Yamazaki T, Nakazato $Y$, Ihara $Y$, Hirai S: Amyloid beta/A4 protein precursor is bound to neurofibrillary tangles in Alzheimer-type dementia. Brain Res 1990, 537:318-322

43. McGeer PL, Akiyama H, Kawamata T, Yamada T, Walker DG, Ishii T: Immunohistochemical localization of beta-amyloid precursor protein sequences in Alzheimer and normal brain tissue by light and electron microscopy. J Neurosci Res 1992, 31:428-442

44. Perry G, Richey PL, Siedlak SL, Smith MA, Mulvihill P, DeWitt DA, Barnett J, Greenberg BD, Kalaria RN: Immunocytochemical evidence that the beta-protein precursor is an integral component of neurofibrillary tangles of Alzheimer's disease. Am J Pathol 1993, 143:15861593

45. Caputo CB, Sobel IR, Scott CW, Brunner WF, Barth PT, Blowers DP: Association of the carboxy-terminus of beta-amyloid protein precursor with Alzheimer paired helical filaments. Biochem Biophys Res Commun 1992, 185:1034-1040

46. Philippe B, Brion JP, Coppens E, Octave JN: Generation of a monoclonal antibody to the carboxy-terminal domain of tau by immunization with the amino-terminal domain of the amyloid precursor protein. J Neurosci Res 1996, 46:709-719

47. Caputo CB, Sygowski LA, Scott CW, Sobel IR: Role of tau in the polymerization of peptides from beta-amyloid precursor protein. Brain Res 1992, 597:227-232

48. Ittner LM, Gotz J: Amyloid-beta and tau: a toxic pas de deux in Alzheimer's disease. Nat Rev Neurosci 2011, 12:65-72

49. Morris M, Maeda S, Vossel K, Mucke L: The many faces of tau. Neuron 2011, 70:410-426 